\title{
The composition of groundwater in Palaeogene and older formations in the Netherlands. A synthesis
}

\author{
Jasper Griffioen ${ }^{1,2, *}$, Hanneke Verweij ${ }^{3}$ \& Roelof Stuurman ${ }^{4}$
}

1 TN0 Geological Survey of the Netherlands, P.0. Box 80015, 3508 TA Utrecht, The Netherlands

2 Copernicus Institute of Sustainable Development, Utrecht University, P.0. Box 80115, 3508 TC Utrecht, The Netherlands

3 TN0 Petroleum Geosciences, P.0. Box 80015, 3508 TA Utrecht, The Netherlands

4 Deltares, unit Soil and Groundwater Systems, P.0. Box 85467, 3508 AL Utrecht, The Netherlands

* Corresponding author: Email: jasper.griffioen@tno.nl

Manuscript received: 3 June 2015, accepted: 19 May 2016

\section{Abstract}

There is increasing interest in the exploitation of the deep subsurface of the Netherlands for purposes other than conventional oil and gas production, such as geothermal energy, shale gas exploitation and the disposal of radioactive waste, so for technical and environmental reasons it is important to understand the composition of the deep groundwater. A synthesis has been made of almost 200 existing groundwater analyses for the Oligocene and older formations in the Netherlands. Three groundwater categories are considered: (1) deep oil and gas reservoirs, (2) deep, buried and confined aquifers and (3) shallower, semi-confined aquifers with or without outcrop areas nearby. No distinct water types are found but a continuous series, with $\mathrm{Cl}$ ranging from around 10,000 to $200,000 \mathrm{mgl}^{-1}$ : the highest concentrations are found in the reservoirs and the lowest in the semi-confined aquifers. The most saline brines are found in the northern onshore area and adjacent offshore area, where Permian and Triassic rock salt also occurs regionally in the subsurface. The groundwater is usually pH-neutral, saturated in carbonates and anaerobic. Anhydrite saturation occurs when the $\mathrm{Cl}$ concentration exceeds $100,000 \mathrm{mg} \mathrm{l}^{-1}$, and halite saturation occurs at $\mathrm{Cl}$ concentrations close to $200,000 \mathrm{mg} \mathrm{l}^{-1}$. Few tracer analyses have been done for $\delta^{2} \mathrm{H}-\mathrm{H}_{2} \mathrm{O}, \delta^{18} 0-\mathrm{H}_{2} \mathrm{O}, \delta^{37} \mathrm{Cl}, \mathrm{Br}$, $\mathrm{Li}$ and $\mathrm{B}$, which makes a rigorous palaeohydrological interpretation impossible. Lithium and $\mathrm{B}$ may be controlled by water-rock interaction which makes them less suitable as tracers. Some of the analyses suggest that dissolution of rock salt plays a role in determining the salinity of groundwater for some deep wells in the southern part of the Netherlands, whereas other analyses suggest that evaporated seawater influences the salinity in the associated wells. Cation-exchange patterns and alkalinity to Ca ratios indicate that groundwater in the deep, buried and shallow, semi-confined aquifers is usually freshening. $\mathrm{Six}^{14} \mathrm{C}$ analyses of samples from the buried aquifers indicate an apparent age of at least 20,000 years. $\mathrm{Six} \delta^{37} \mathrm{Cl}$ analyses of formation waters from reservoirs in South-Holland suggest diffusion of $\mathrm{Cl}$ from a brine towards fresher water, and the associated $\mathrm{K}$ and also Li concentrations further suggest that these brines are related to rock salt dissolution and are not the residue of evaporated seawater. The high Ca concentrations are enigmatic for the hypersaline formation waters in the reservoirs. A limited series of samples had been analysed for various trace elements. The median concentrations are similar to the seawater and Dutch background concentration limits for shallow groundwater, but maximum concentrations can be up to three orders of magnitude higher. In conclusion, the data synthesis shows that the composition of groundwater in reservoirs and aquifers of Palaeogene and older age varies strongly in salinity at the national scale. Presence of evaporite deposits and diffusive transport seem to play important roles in controlling the salinity. Many existing analyses have no or only a few tracer analyses, that even vary among the samples. A complete suite of analyses is needed to elucidate the hydrogeological and geochemical processes that control the groundwater composition.

Keywords: groundwater composition, petroleum reservoirs, hydrogeochemistry, brine, aquifers

\section{Introduction}

Anthropogenic activities in the deep subsurface of the Netherlands are still largely limited to exploitation of natural gas, oil and rock salt, but interest is growing in other activities (e.g. exploitation of geothermal energy, storage of $\mathrm{CO}_{2}$, underground disposal of radioactive waste, storage in salt caverns and shale gas exploitation) and there is potential for several of these 
in the Netherlands. Some of these activities (geothermal energy and $\mathrm{CO}_{2}$ storage, for example) are directed at exploited oil and gas reservoirs, while others are directed at geological units that have previously received little attention: for example, the Oligocene Rupel Clay (also known as Boom Clay, but here we use the official name according to Dutch lithostratigraphic terminology; see De Mulder et al., 2003), which is considered a potential host rock for the geological disposal of radioactive waste in the Netherlands and Belgium because of the isolating potential of its poorly permeable, clay-rich rocks (Verhoef et al., 2014).

It is important to know about the composition of groundwater under the Rupel Clay because it serves as the lower boundary condition for pore water within the Rupel Clay where diffusion, chemical osmosis or even advection may cause transport into or out of the Rupel Clay at the geological time scale. This groundwater also provides the background composition for radionuclides that might migrate from the base of the Rupel Clay, move further via groundwater transport in adjacent aquifers and in the long term might ultimately reach the biosphere. The Rupel Clay is part of a sequence of clay-rich Palaeogene and Neogene sediments which are widespread across the Netherlands (De Mulder et al., 2003; Vis et al., 2016). A consequence is that this sequence of sediments also serves as a divide between an upper groundwater compartment where advective flow is driven by precipitation excess and topography in free-draining areas and by fixed surface water heads in polders and a lower compartment with rather stagnant conditions for groundwater flow. In the latter, diffusion, compaction-driven flow and density-driven flow are operational processes at the geological time scale (Verweij, 2003). It is, therefore, practically assumed that the hydrological base level for the upper groundwater compartment in the Netherlands is the top of the Breda Formation or that of the 0osterhout Formation, which are both from the Neogene period (Dufour, 2000; cf. De Vries, 2007).

The deep subsurface thus coincides with a groundwater compartment that is essentially different from the shallower surface-driven one. There are several good reasons in addition to those mentioned above why it is important to know about the composition of deep groundwater (cf. Smalley \& Warren, 1994): to understand the diagenesis of reservoir rocks, to determine the nature of basin plumbing and its hydraulic effects, to estimate water resistivity and density for the interpretation of geophysical measurements, to estimate the risks of scaling and corrosion of pipelines, to assess compatibility with injected fluids (aqueous and non-aqueous), and to establish natural background compositions (in relation to environmental and health risks as well as sustainability of subsurface storage and disposal). Clearly there is an overall need for insight into the composition of deep groundwater with respect to both the major groundwater composition (i.e. the species that control the salinity, carbonate state and redox state) and the background concentration of trace elements that are of environmental and health concern.
Several studies have addressed the composition of deep groundwater in the Netherlands, but they were usually locally oriented (e.g. Kimpe, 1963; Glasbergen, 1981, 1985; Zuurdeeg \& Coenegracht, 1986) or focused on the typology of the major element composition (Verweij, 2003). They found that the presence of evaporites greatly influences the salinity and related major ion composition of deep groundwater. However, until now there has been no broad overview, and trace elements have received minor attention. Data on iodine and selenium are interesting in relation to the subsurface disposal of radioactive waste because ${ }^{129} \mathrm{I}$ and ${ }^{79} \mathrm{Se}$ are long-lived radioisotopes (halflives of $1.61 \times 10^{7}$ and $3.25 \times 10^{5}$ years, respectively) present in radioactive waste. Data on other trace elements such as toxic heavy metals are interesting in relation to the re-injection of formation water produced during natural gas and oil production or the injection of the concentrates that are produced during reverse osmosis of brackish groundwater or surface water.

We set out to characterise the groundwater composition in Palaeogene and older geological units for the onshore and offshore European territory of the Netherlands. The Miocene Breda Formation lies immediately above the Palaeogene formations in many parts of the Netherlands. This study thus deals with the geological units below this base level, where advective groundwater flow is minimal, except in the areas close to the border with Belgium and Germany, where the Palaeogene, Cretaceous and Carboniferous units often lie closer to the surface.

\section{Geological and hydrogeological settings}

The Netherlands is part of the southern North Sea sedimentary basin. Geological characteristics and past and present geological processes of different duration have influenced present-day pressure, groundwater flow and hydrochemical conditions to a greater or lesser extent. Detailed information on the geology of the Netherlands can be found elsewhere (e.g. Van Adrichem Boogaert \& Kouwe,1997; Wong et al., 2007). A summary of important features concerning the geological and hydrogeological setting of influence on present-day pressure and fluid flow conditions, largely taken from Verweij (2003) and Verweij et al. (2011, 2012), is given below. Figure 1 presents the main tectonic features and Table 1 provides an overview of the main permeable units of Palaeogene and older age present in the Netherlands.

\section{Burial history}

The burial history of an aquifer or reservoir, i.e. the history of sedimentation, uplift, erosion and non-deposition, is a potential geological factor of influence on present-day pressure and groundwater flow conditions. There are important regional differences in sedimentation and erosion history in the study area (Verweij, 2003; Nelskamp and Verweij, 2012; Verweij et al., 2012). At the large scale, the southern North Sea is a basin 


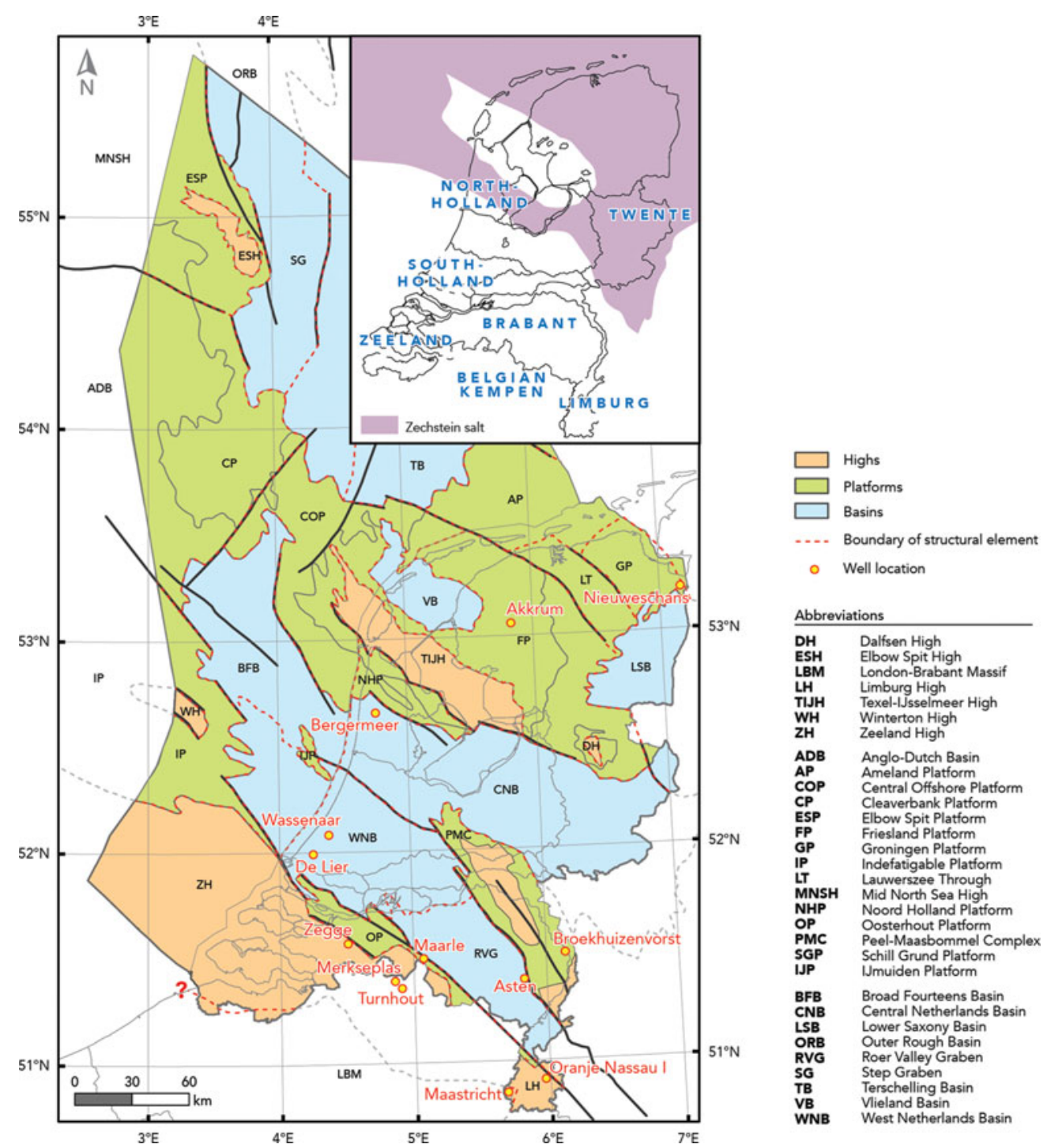

Fig. 1. Map of the Netherlands showing structural elements (after Kombrink et al., 2012) and the well locations, with inside map showing the areal extent of Zechstein salt and the regions referred to in the text.

dominated by rifting during most of the Mesozoic Era and that has been in a post-rift sag phase since the Late Cretaceous Period (except for the Roer Valley Graben in the southern Netherlands: Van Balen et al., 2005). Permian Rotliegend sandstones form the main hydrocarbon gas reservoirs within this basin, where the gas originates from Carboniferous deposits. These sandstones were deposited in aeolian and fluvial environments and accumulated in a non-marine basin that subsequently transformed into the Zechstein Sea. During the Late Permian Period, evaporites precipitated from the Zechstein Sea. The evaporite sequence comprises carbonates via anhydrite to halite and eventually silvite. This sequence may be present laterally, in agreement with surface water systems draining northwards (Platt, 1994). These evaporites, in particular the rock salt, are the main seal to the Rotliegend sandstone reservoirs.

The area became predominantly terrestrial again during the Early Triassic Period, with the Variscan Mountains to the south being the provenance area for the related sediments. A heterogeneous series of sediments was subsequently deposited, comprising claystone, evaporites and chalk, but few sandstones. During the Triassic and Jurassic periods, the single, southern Permian Basin transformed into a series of smaller fault-bounded basins and highs. Salt tectonics played a major role in large parts of the southern North Sea Basin, mobilising the Zechstein evaporites and resulting in salt diapirs that intruded into overlying Mesozoic or even Palaeogene sediments. The related Kimmerian tectonic phase induced a development where sediments accumulated in the rift basins such as the Broad Fourteens and West Netherlands basins during the Late Jurassic-Early Cretaceous periods and there was erosion of the existing platforms and highs. During this period, important gas and oil reservoirs were generated in these basins, where the source rocks are both Carboniferous and Jurassic. The accumulation of sediments in the subsiding basins induced 
Table 1. The main permeable units in Palaeogene and older formations in the Netherlands (major oil and gas reservoirs in bold and italic; compiled from Bless, 1981; Verweij, 2003; Wong et al., 2007).

\begin{tabular}{|c|c|c|}
\hline Age & Stratigraphic group & Permeable units \\
\hline Oligocene & Middle North Sea Group & $\begin{array}{l}\text { Voort Member (Veldhoven } \\
\text { Formation), Vessem Member } \\
\text { (formerly Berg Sand and Kallo } \\
\text { Complex; Rupel Formation) }\end{array}$ \\
\hline Eocene & Lower North Sea Group & $\begin{array}{l}\text { Brussels Sand Member (Dongen } \\
\text { Formation) }\end{array}$ \\
\hline Late Cretaceous & Chalk Group & $\begin{array}{l}\text { Houthem Formation when } \\
\text { karstified or fissured/faulted }\end{array}$ \\
\hline Early Cretaceous & Rijnland Group & $\begin{array}{l}\text { Vlieland Sandstone Formation, } \\
\text { sandstone members }\end{array}$ \\
\hline $\begin{array}{l}\text { Late Jurassic / Early } \\
\text { Cretaceous }\end{array}$ & $\begin{array}{l}\text { Schieland, Scruff and } \\
\text { Niedersachsen Groups }\end{array}$ & Sandstone members \\
\hline $\begin{array}{l}\text { Middle and Late } \\
\text { Triassic }\end{array}$ & $\begin{array}{l}\text { Upper Germanic Triassic } \\
\text { Group }\end{array}$ & Solling Formation \\
\hline Early Triassic & $\begin{array}{l}\text { Lower Germanic Triassic } \\
\text { Group }\end{array}$ & Sandstone members \\
\hline Late Permian & Zechstein Group & Carbonate members \\
\hline $\begin{array}{l}\text { Middle and Late } \\
\text { Permian }\end{array}$ & Upper Rotliegend Group & $\begin{array}{l}\text { Sandstone members of } \\
\text { Slochteren Formation }\end{array}$ \\
\hline Late Carboniferous & Limburg Group & Sandstone members \\
\hline Late Devonian & Banjaard Group & Sandstone \\
\hline
\end{tabular}

compaction-related groundwater flow in the basins. The recharge of meteoric water in adjacent subaerial platforms and highs could enter the basins along the basin boundaries to some extent (Lee et al., 1989; Verweij et al., 2003). Widespread deposition of chalk occurred during the Late Cretaceous Period, due to regional subsidence.

The burial history from the Late Cretaceous Period onwards includes the following features. The widespread deposition of chalk was interrupted in the Mesozoic basins by inversion movements during the Late Cretaceous Sub-Hercynian tectonic phase. The central parts of the Broad Fourteens, Central Netherlands and West Netherlands Basins and Roer Valley Graben experienced strong uplift and erosion, while chalk deposition continued in adjacent areas. The Laramide regional phase of erosion terminated the deposition of chalk and was followed by regional subsidence of the Cenozoic North Sea Basin and deposition therein of predominantly marine clays with sandy deposits along the southern edge of the basin. The regional subsidence was interrupted again by the Late Eocene-Early Oligocene Pyrenean tectonic phase. This phase involved uplift and erosion of the southern onshore (West Netherlands Basin) but also extended westward into the Broad Fourteens Basin (Nalpas et al., 1995). During the Oligocene Epoch, the sea transgressed across previously eroded areas, resulting in marine deposits of the Middle North Sea group (including the Rupel Clay). Sedimentation was interrupted again at the end of the Oligocene (Savian phase of erosion). In the Neogene, deltas prograded from the south and southeast of the Netherlands and from Fennoscandinavia into the North Sea.

The West Netherlands Basin was uplifted and eroded during the Pyrenean and Savian phases, and sedimentation and subsidence were limited during the Neogene. In contrast, the Roer Valley Graben and Zuiderzee Basin (located in the Mesozoic Central Netherlands Basin) developed into depocentres. The Roer Valley Graben was reactivated and developed as part of the northwest European rift system from the Late Oligocene 
onwards (Michon et al., 2003; Van Balen et al., 2005; Worum et al., 2005) and its subsidence accelerated during the Pliocene and Quaternary.

\section{Lithostratigraphic build-up}

The Carboniferous to recent lithostratigraphic build-up of the study area includes the following stratigraphic groups of large areal extent: Carboniferous Limburg Group (main gas source rock), Permian Upper Rotliegend Group (containing the main gas reservoir), Upper Permian Zechstein Group (the main caprock), Cretaceous siliciclastic Rijnland Group and Chalk Groups, and the Cenozoic clastic North Sea groups. The presence of the Germanic Trias Groups and marine clays of the Jurassic Altena Group (including the oil-prone Posidonia source rock) is more scattered. The greatest thickness of these groups occurs in the Mesozoic basins (such as the West Netherlands Basin, Roer Valley Graben and offshore Broad Fourteens Basin). The current distribution of the Late Jurassic to earliest Cretaceous Schieland, Scruff and Niedersachsen groups is also restricted to the Mesozoic basins.

The position of the Netherlands at the southern edge of large basins during most of its post-Carboniferous geological history has directly affected the facies distribution of the deposited sediments. Generally, more coarsely grained clastic sediments occur in the south. The Upper Rotliegend sediments consist of the coarser-grained clastics (conglomerates and sandstones of fluvial and aeolian origin) of the Slochteren Formation that grades northward into the finer-grained desert-lake deposits of the Silverpit Formation (Grötsch and Gaupp, 2011). The marine Zechstein evaporites, carbonates and clays overlie the Upper Rotliegend Group. The southern limit of the Zechstein salts runs through the southern part of the Broad Fourteens Basin and Central Netherlands Basin. In the south the Zechstein is predominantly clastic. As already noted, in large parts of the southern North Sea Basin salt tectonics mobilised the Zechstein evaporites and resulted in salt diapirs that intruded overlying Mesozoic and even Palaeogene sediments. During the Early Triassic the area became predominantly terrestrial and erosion of the Variscan Mountains to the south produced the related sediments. The Lower Germanic Trias Group consists of lacustrine claystones and aeolian and fluvial sandstones, whereas the Upper Germanic Trias group consists mainly of lascustrine and shallow marine claystones, carbonates and evaporites (Röt to Keuper units). The distribution is most widespread for the Röt Formation and overlaps considerably with that of Zechstein salt. The Muschelkalk Evaporite Member also contains halite further south than the Zechstein: local occurrences are found in the West Netherlands Basin and in the Roer Valley Graben.

\section{Hydrogeological setting}

The most important lithostratigraphic units controlling formation water pressure distribution and flow conditions in the
Dutch subsurface are the Salt Members of the Zechstein Group, because of their extremely low permeability and their large regional continuity. An important role is also played by the evaporite members of the Upper Germanic Trias Group (such as those of the Röt and Keuper formations). The southern limit of the Zechstein salts runs through the southern part of the Broad Fourteens Basin and Central Netherlands Basin. In the south the Zechstein is predominantly clastic. The remaining poorly permeable units consist of claystones/mudstones/clays. The more permeable stratigraphic units consist of sands, sandstones and carbonates: Table 1 presents an overview of the relevant permeable units as groundwater aquifers or oil and gas reservoirs, where several groundwater analyses were available for most of them.

Regional facies distributions over the onshore and offshore Netherlands result in generally more permeable facies in the south and an increasing number of interspersed sealing layers towards the northern part of the study area. Hence, in the north there are more vertical barriers to flow that slow down pressure dissipation. In addition, numerous deep faults and elongated salt structures disrupt the lateral hydraulic continuity of preCenozoic hydrostratigraphic units. Large elongated poorly permeable salt structures related to basin boundary faults occur especially along the northeastern edge of the Broad Fourteens Basin and Lauwerszee Trough.

\section{Palaeogroundwater flow conditions}

The current hydrochemistry of pore water has been influenced to a greater or lesser extent by palaeogroundwater flow conditions. Two important palaeo types of regional groundwater flow identified in the study area are flow induced by sedimentary loading and flow induced by topography. Sedimentary loading may result in expulsion of pore water from clastic sediments, as well as expulsion of residual brines from evaporate deposits. All periods of sedimentation induce either compaction of the sediments and expulsion of pore water or create overpressured conditions in the sediments. The largest influence occurs during prolonged periods of rapid sedimentation. Topography-induced flow may introduce fresh groundwater of meteoric origin into reservoirs or aquifers. Large-scale northward-flowing systems have been identified, originating at the southern and southeastern margins of the Netherlands during different times in geological history (Late Carboniferous - Early Permian; Jurassic - Early Cretaceous; recent: Verweij, 1999). Diagenetic evidence exists that meteoric water infiltrating in the subaerial exposed Texel Ijsselmeer High entered the Permian Rotliegend reservoir in the northern part of the Netherlands during the Early Cretaceous, giving rise to the flushing of this reservoir (Lee et al., 1989). During the Late Cretaceous inversion of the centres of the West Netherlands and Broad Fourteens Basins, topography-induced flow developed, reaching Lower Cretaceous and possibly deeper reservoir units (e.g. Bouw and Oude Essink, 
2003; Verweij, 2003). Activated fault zones may create vertical pathways for groundwater flow. This has been identified for tectonically active periods, such as Jurassic rifting and Late Cretaceous inversion in, for example, the Broad Fourteens Basin (Verweij \& Simmelink, 2002; Verweij, 2003).

\section{Current pressure and groundwater flow conditions}

The present-day depths to which local and regional topographyinduced groundwater flow systems originating in the Netherlands lowland area penetrate are in the order of tens to hundreds of metres (e.g. De Vries, 2007). The recharge areas of supraregional groundwater flow systems are the Belgian Kempenland and Ardennes, and the German Eifel, Sauerland and Teutoburger Wald and their offshoots (Verweij, 2003). An important part of this supraregional flow is concentrated in the Roer Valley Graben (Luijendijk, 2012), where meteoric water has been able to infiltrate since the Miocene. Most flow in the graben is concentrated in the upper $250-500 \mathrm{~m}$.

In the southern Netherlands there are a few groundwater head monitoring wells with deep screens in the Palaeogene or Cretaceous Houthem Formations. Three locations in the Roer Valley Graben and Venlo Graben indicate artesian conditions in the recent past (Stuurman, 2000, 2004). Hydraulic head measurements indicate the heads have dropped by $10-50 \mathrm{~cm} \mathrm{a}^{-1}$ in response to lignite mining across the border in Germany or for other reasons. The present situation is thus far from representative of the natural situation. In Kempian Plateau and western Brabant, one of the three wells with screens in the Palaeogene aquifer shows artesian conditions at present (www.dinoloket.nl). A seventh location at the Peel Horst, where the screen depth is around $100 \mathrm{~m}$ (rather than the several hundred metres that is the case for the other, more westerly wells), does not currently have artesian conditions (Stuurman, 2004). Further, two screens in Carboniferous and Devonian aquifers in Maastricht have piezometric heads a few metres above surface level (Glasbergen, 1985). A major shortcoming in these data is that no correction has been made for temperature and salinity.

The groundwater condition below the penetration depth of topography-induced groundwater flow can be characterised by the distribution of pore water overpressure. The overpressure of pore water at a certain depth is the difference between the measured pore pressure and the hydrostatic pressure at that depth. Gradients in overpressure are related to hydraulic head gradients. Keijzer (2000) and Garavito Rojas (2006) recognised that buried clay layers such as the Rupel Clay may induce chemical osmosis and thereby impact on hydraulic heads because they may act as semi-permeable membranes. There is no field evidence that further illustrates the relevance of this transport mechanism at the local or regional scale.

Published information on the distribution of overpressure (Verweij et al., 2011, 2012) indicates overpressured conditions in Carboniferous, Upper Rotliegend and Triassic sandstone units in the northern and northeastern parts of the onshore Netherlands. Here the permeability framework is affected by lateral and vertical permeability barriers created by Zechstein and Triassic salt depots and structures, restricting the flow of water. Near-normal pressure occurs in the southern onshore and offshore areas (e.g. West Netherlands Basin, Roer Valley Graben). Faults are known to restrict water and gas movement in the deeper subsurface, where differences in overpressure have been observed (Corona, 2005; Van Hulten, 2010; Verweij et al., 2012). Bense et al. (2003) and Caro Cuenca (2012) showed that faults in the normally pressured Roer Valley Graben hamper shallow groundwater flow. The mechanisms that cause this sealing are smearing of clay along the fault plane, the juxtaposition of lithologies having strongly contrasting hydraulic conductivities, diagenetic salt plugging, or cementing by carbonates, sulphates or oxides. The latter three mechanisms (juxtaposition, salt plugging, cementing) have frequently been described for the southern North Sea Basin (Geluk, 2007b; Gaupp \& 0kkerman, 2011).

\section{Data}

\section{Groundwater analyses}

Groundwater analyses were retrieved from a series of studies that deal with the composition of groundwater in Oligocene and older units: Jongmans \& Driessen (1932), Kimpe (1963), TN0 (1974), Bless (1981), Glasbergen $(1981,1984)$, Van der Weiden (1983), Coenegracht et al. (1984), Zuurdeeg et al. (1984), Zuurdeeg \& Coenegracht (1986), Core Lab (1987), Heederik (1989), CME0 (1991), Beaucaire et al. (2000), Verweij (2003) and Griffioen (2015). Data on groundwater composition in the Palaeogene aquifers in Zeeland were obtained from the DINO (Data and Information of the Dutch Subsurface) database. Not all data on the gas and oil reservoirs in South-Holland are included in this study because the compositions are very similar and bias would have resulted if all available data had been included compared to the amount of data from other Dutch reservoirs. The samples with the highest and lowest concentrations were selected per field, where this difference was usually less than $5 \%$ of the average concentration and $20 \%$ at most. Of the total of 113 analyses, 31 were included. No averaging was preferred, as this may obscure interrelationships among equilibrium-controlled concentrations. These data were extended with some analyses performed in the context of the re-injection of formation water produced during gas or oil exploitation. The data of Beaucaire et al. (2000) deal with groundwater in the Belgium Oligocene aquifer where the Rupel Clay lies at a relatively shallow depth $(<490 \mathrm{~m})$. All samples available originate from the onshore Netherlands, the Broad Fourteens Basin and the Central Offshore Platform west of this; no data were available for the northern offshore part of the Netherlands. 
Analyses were considered when they contained several major compounds. When complete analyses were available $\mathrm{(pH}, \mathrm{Ca}$, $\mathrm{Mg}, \mathrm{Na}, \mathrm{Cl}, \mathrm{SO}_{4}$, alkalinity, preferably also $\mathrm{K}, \mathrm{NH}_{4}, \mathrm{Mn}$ and $\mathrm{Fe}$, with $\mathrm{Al}$ and $\mathrm{NO}_{3}$ usually below detection limit), we selected the analyses which had a good electroneutrality (EN) condition. A good EN condition was defined as follows:

$$
\begin{aligned}
& -5.0 \%<\mathrm{EN}=(\text { sumcations }- \text { sumanions }) / \text { sumcations } \\
& + \text { sumanions })<5.0 \%
\end{aligned}
$$

Sometimes, several analyses were available for a sampling location. If they were very similar, only one analysis was selected: the most complete analysis having the least number of variables below detection limit. The resulting dataset comprised almost 200 samples.

In general, the analytical quality of the data was remarkably good when checked for EN condition: most samples had an EN condition less than $0.5 \%$. In general, the agreement between the different analyses per screen was also good. For the Zeeland series (see Fig. 1 for location), a well with two screens having different depths showed a remarkable difference in composition between the sampling round in 1995 and the samples taken in 2006-2007: for both well screens, $\mathrm{Cl}$ in 1995 was around $100 \mathrm{mgl}^{-1}$ but in 2006-2007 was around $2600 \mathrm{mg} \mathrm{l}^{-1}$. No further investigation was made at this location and the different samples remained in the database. For t1gxhe Twente series, a well having its screen at $44-60 \mathrm{~m}$ below surface in the Lower Cretaceous sandstone showed remarkable $\mathrm{pH}$ of 3 and Fe concentration of $680 \mathrm{mg} \mathrm{l}^{-1}$ with high $\mathrm{SO}_{4}$ of $2590 \mathrm{mgl}^{-1}$ as well; check on the EN condition could not be performed because Na was lacking. This analysis was excluded although it might be due to pyrite oxidation under open-air conditions due to historical groundwater overexploitation of pre-Quaternary aquifers in the Twente area. As almost all the literature sources of the chemical data provided no details of the sampling and conservation procedures, the quality of the data cannot be assessed. As discussed by Verweij (2003), the quality of chemical analyses of formation waters may be questionable, particularly because of contamination with mud filtrate. of the formation water samples collected by Verweij (2003), the ones selected for this study were those considered to be 'representative' or 'probably representative'; those that the analysing laboratories reported to be either mud filtrate or formation water heavily contaminated with mud filtrate were excluded. The $\mathrm{pH}$ is particularly susceptible to changes during sampling, even when there is no actual contamination from drilling, because of the difference in temperature between the reservoir and the earth's surface (where the $\mathrm{pH}$ is measured), and the $\mathrm{CO}_{2}$ degassing during transport into the well. We used the reported $\mathrm{pH}$ values without adjusting them; however, our calculated saturation indices for Ca carbonates must be viewed with caution. Here, saturation index (SI) refers to the log value of the ratio between the ion activity product and solubility constant for a mineral: 0 indicates thermodynamic equilibrium conditions, below 0 undersaturation, where the mineral may dissolve when present, and above 0 supersaturation, where the mineral could precipitate.

\section{Geochemical calculations}

For speciation calculations, no temperature data were available for many analyses of groundwater under the Rupel Clay. They were therefore calculated as:

$$
\text { Temp (sample })=10^{\circ} \mathrm{C}+\operatorname{depth}(\text { sample }) \times 30^{\circ} \mathrm{C} \mathrm{km}^{-1}
$$

where depth is given in $\mathrm{km}$ and $30^{\circ} \mathrm{C} \mathrm{km}^{-1}$ represents the temperature gradient for the Dutch subsurface (Verweij, 2003; Bonté et al., 2012). When the calculated temperature was compared with the few measured temperatures as available for reservoirs at about $1800 \mathrm{~m}$ depth, the latter were $35-40^{\circ} \mathrm{C}$ lower. This implies erroneous measurements due to cooling, e.g. during pumping. Preference was given to the calculated temperature instead of the reported temperature, as we considered it to be more robust.

We performed the speciation calculations for the groundwater analyses with PHREEQC version 3 (Parkhurst \& Appelo, 2013). Both the Pitzer procedure and the regular Debye-Hückel procedure were used to calculate the aqueous activities of ions from the total concentrations for analyses of groundwater under the Rupel Clay. We used the recently released and improved Pitzer database (Appelo, 2015). The groundwater below the Rupel Clay has repeatedly been found to be a brine with $\mathrm{Cl}$ concentrations up to $200,000 \mathrm{mg} \mathrm{l}^{-1}$. The Pitzer procedure is more suitable for correcting for aqueous activity than the regular procedure for brines, but the associated database on the solubility of minerals and the temperature dependency of chemical equilibria is smaller. It does not contain Fe as element, so no calculations can be performed for diagenetic Fe minerals such as siderite $\left(\mathrm{FeCO}_{3}\right)$, which is an important mineral in reservoirs and aquifers. In addition to its limited extent, the Pitzer database has some intrinsic shortcomings (Appelo, 2015; Rowland et al., 2015). A drawback of the regular database is the incorrect calculation procedure used to correct the concentration to activity for saline water. We used both databases to compile a dataset for groundwater under the Rupel Clay. Figure 2 compares the results for the SIs of halite and anhydrite as the difference between the two SI values per sample vs the sample's $\mathrm{Cl}$ concentration. The data show that the discrepancy is in the order of several tenths of a unit for halite and that for anhydrite it varies between several tenths of a unit and, at most, 2 units. The biggest discrepancy is found for the brines that in situ have a high temperature of about $100-130^{\circ} \mathrm{C}$ (i.e. the deepest samples); a smaller discrepancy is found when the in situ temperature is around $25^{\circ} \mathrm{C}$ (i.e. shallower samples). This illustrates that the temperature correction of the thermodynamic 

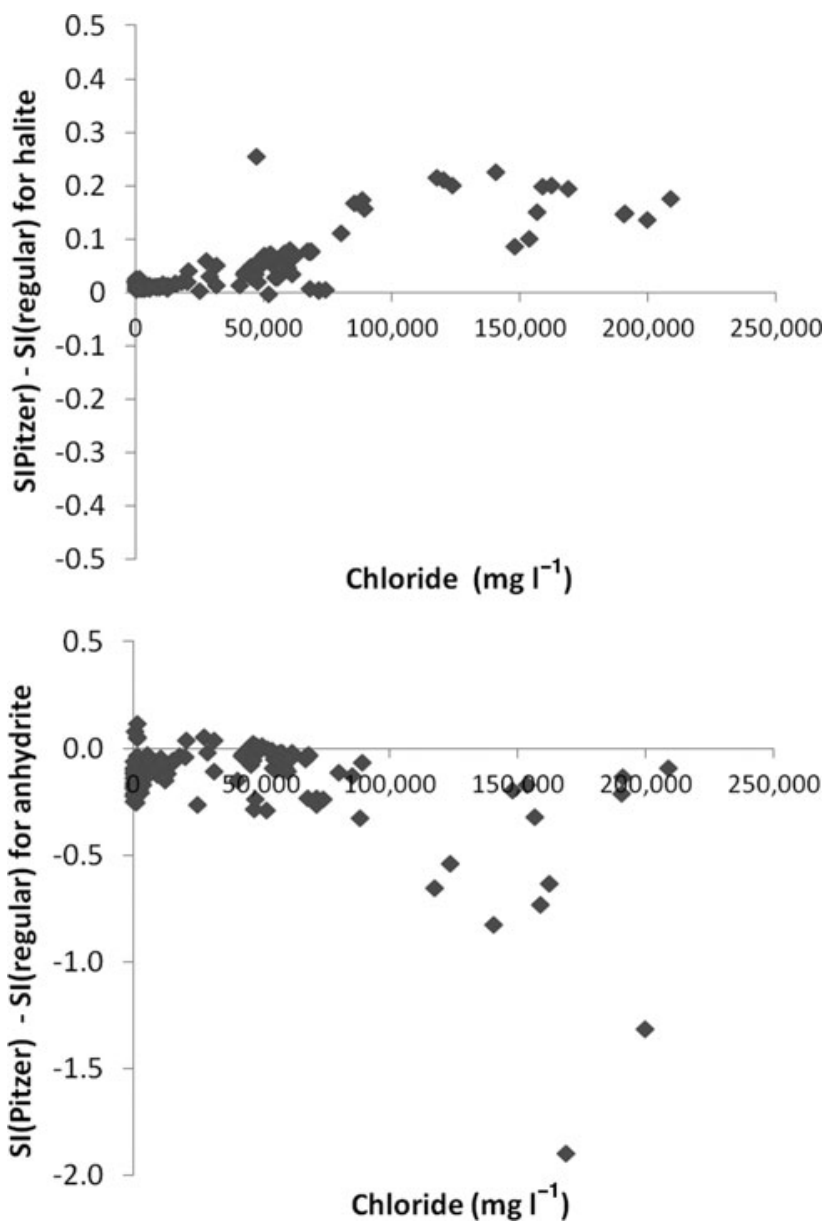

Fig. 2. Relationship between the $\mathrm{Cl}$ concentration and the difference between the saturation indices of halite (above) and anhydrite (below) as calculated according to the Pitzer and regular procedures for the dataset considered.

equilibria is important, in addition to the method used to calculate the activity. Here, the findings for calcite are similar to those for anhydrite. Preference was given to using the Pitzer procedure, but the regular database was used for calculations of Fe minerals.

To further test the assumption on the temperature calculation, a straightforward sensitivity analysis was performed by calculating the SI for a range of temperatures. The temperature dependency of the SI was somewhat dependent on the aqueous composition and mostly between -0.010 and +0.010 SI unit per degree Celsius. An error in temperature estimate of $10^{\circ} \mathrm{C}$ thus results mostly in an error in SI of \pm 0.1 or less.

\section{Results and discussion}

The hydrochemical data available for groundwater under the Rupel Clay can be separated into three groups: (1) Data on shallow $(<100 \mathrm{~m}$ ) to deep (mostly down to $560 \mathrm{~m}$, with 6 out of 62 sampling locations between 680 and $860 \mathrm{~m}$ ) groundwater in the former coal-mining district in southern Limburg, Zeeland, Twente and the Belgian Kempen region, where Palaeogene and older sediments lie close to or at the surface. Note that three of these areas lie in the London Brabant Massif and related Zeeland and Limburg Highs (Fig. 1). The sampling depths range from 30 to $480 \mathrm{~m}$ depth except for the Carboniferous samples from southern Limburg that originate from depths down to $860 \mathrm{~m}$. (2) Data on formation waters in Permian to Early Cretaceous oil and gas reservoirs at 950-4000 m depth (mostly from South-Holland (West Netherlands Basin), northern onshore Netherlands (different basins and platforms), Broad Fourteen and Central Offshore Saddle basins). (3) Other data on groundwater across the Netherlands in Upper Devonian to Palaeogene aquifers and buried deep at several hundreds to $1100 \mathrm{~m}$ depth (and 5 out of 58 sampling locations even between 1360 and $2250 \mathrm{~m}$ below the surface). Here, most samples originate from central Limburg and Brabant where the locations lie in the Peel-Maasbommel Complex, Roer Valley Graben, Oosterhout Platform and Zeeland High (Fig. 1). For the sake of clarity, we will consistently refer to the first group as shallow, semi-confined aquifers, the second as reservoirs and the third as deep, buried aquifers. The behaviour of the Carboniferous rocks in the former coal-mining district in southern Limburg is intermediate between the first and third groups, as the type of overburden varies in thickness and hydrogeological characteristics. Table 2 presents basic statistics on groundwater composition for the three categories, and Figure 1 is a map showing the locations of the wells mentioned in the text. Table 1 serves as reference for the permeable units from which the samples studied originate.

The results of our study will be presented under six headings. First, it is appropriate to present the few findings on carbon isotopes and groundwater dating for limited characterisation of groundwater age, as this provides some boundary conditions with respect to time of infiltration. Subsequently, the major composition will be considered for the three groups, followed by a discussion of the role of diagenesis in the oil and gas reservoirs. Finally, attention is paid to those elements that are commonly found in trace concentrations in groundwater but whose concentrations may be high under the conditions encountered in Dutch deep groundwater.

\section{Groundwater dating}

A small series of six samples contained ${ }^{14} \mathrm{C}$ analysis, two of which originated from Carboniferous and Upper Devonian units at Maastricht (Glasbergen, 1985), with the others from Palaeogene units at Nieuweschans, Broekhuizenvorst, Zegge and Maarle (Table 3). Laboratory analysis of the activity of ${ }^{14} \mathrm{C}$ yields the 'apparent age' of groundwater, because the activity of total inorganic carbon (TIC) is determined and the TIC concentration is the result of all hydrogeochemical processes that have taken place from the infiltration area to the monitoring point. A correction must be made to transform the analysis from apparent 
Table 2. Statistical characteristics of the groundwater composition ( $\mathrm{mgl}^{-1}$, with alkalinity as $\mathrm{mg} \mathrm{HCO}_{3} \mathrm{l}^{-1}$ ) for the three categories distinguished. Only medians are given for data series ranging from 5 to 20 samples.

\begin{tabular}{|c|c|c|c|c|c|c|c|c|c|}
\hline \multirow[b]{2}{*}{ Compound } & \multicolumn{3}{|c|}{$\begin{array}{l}\text { Shallow, semi-confined } \\
\text { aquifers (65 samples) }\end{array}$} & \multicolumn{3}{|c|}{$\begin{array}{l}\text { Deep, buried } \\
\text { aquifers (58) }\end{array}$} & \multicolumn{3}{|c|}{$\begin{array}{l}\text { Deep oil and gas } \\
\text { reservoirs (59) }\end{array}$} \\
\hline & median & 15 -percentile & 85-percentile & median & 15-percentile & 85-percentile & median & 15 -percentile & 85-percentile \\
\hline $\mathrm{pH}$ & 7.7 & 6.9 & 8.5 & 7.5 & 7.0 & 8.4 & 6.4 & 5.5 & 7.2 \\
\hline $\mathrm{Na}$ & 582 & 110 & 4718 & 3480 & 800 & 16,196 & 30,400 & 24,520 & 75,900 \\
\hline $\mathrm{K}$ & 25 & 8.0 & 97 & 67.2 & 27.3 & 213 & 310 & 132 & 2088 \\
\hline $\mathrm{Ca}$ & 46.5 & 12.1 & 242 & 106 & 23.7 & 1434 & 3958 & 2620 & 17,335 \\
\hline $\mathrm{Mg}$ & 19.8 & 4.59 & 102 & 85.1 & 20.0 & 845 & 920 & 734 & 3405 \\
\hline $\mathrm{Li}$ & & & & 1.30 & & & 0.389 & & \\
\hline $\mathrm{Ba}$ & & & & 0.37 & & & 24.5 & 0.21 & 42.7 \\
\hline $\mathrm{Sr}$ & & & & 131.5 & & & 410 & 26.5 & 630 \\
\hline $\mathrm{Fe}$ & 0.71 & 0.08 & 11.7 & 3.53 & 0.62 & 14.9 & 35 & 16.6 & 419 \\
\hline $\mathrm{Mn}$ & 0.21 & trace & 5.0 & 0.2 & & & 1.38 & & \\
\hline $\mathrm{NH}_{4}$ & 1.16 & 0.29 & 2.38 & 11.9 & & & & & \\
\hline $\mathrm{SiO}_{2}$ & 15.35 & 9.35 & 50.1 & 18.5 & & & 102 & & \\
\hline $\mathrm{Cl}$ & 460 & 24.8 & 3198 & 5200 & 968 & 29,271 & 59,130 & 46,680 & 160,000 \\
\hline $\mathrm{SO}_{4}$ & 43.2 & 2.53 & 703 & 93.7 & 13.5 & 613 & 78.8 & $<1$ & 507 \\
\hline Alkalinity & 458 & 199 & 795 & 595 & 261 & 948 & 231 & 92.5 & 546 \\
\hline B & & & & 17.9 & & & 28.4 & & \\
\hline $\mathrm{F}$ & & & & 0.5 & & & & & \\
\hline $\mathrm{Br}$ & & & & 41.7 & & & & & \\
\hline I & & & & 2.5 & & & & & \\
\hline
\end{tabular}

age into true age. This may be very complicated, depending on the hydrogeological settings, the hydrogeochemical processes that affected the carbonate chemistry along the groundwater flow path, and the related origin and age of mineralised solid organic carbon or dissolved inorganic carbon. We did not attempt to correct the apparent age to true age because these conditions are insufficiently clear for the individual samples.

The laboratory analysis indicates that two samples had ${ }^{14} \mathrm{C}$ activity below the detection limit of 2 PMC (per cent modern carbon). This yields an apparent age of at least 32,000 years according to the following formula:

$$
\text { apparent age }=\frac{-5736 \ln \left(\frac{\text { analysis }}{100}\right)}{\ln 2}
$$

where analysis refers to the ${ }^{14} \mathrm{C}$ activity of the sample in per cent modern carbon. The other four samples had ${ }^{14} \mathrm{C}$ activities of 0.4-9 PMC and thus apparent ages of 20,000-46,000 years. The true age will be lower, as radiogenic ${ }^{14} \mathrm{C}$ becomes 'diluted' by ${ }^{14} \mathrm{C}$-free or ${ }^{14} \mathrm{C}$-poor solid reactants such as carbonate minerals or sedimentary organic matter (Clark \& Fritz, 1997). The low ${ }^{14} \mathrm{C}$ activities, however, make it unlikely that these groundwaters are younger than 10,000 years or thereabouts. As discussed later, few $\delta^{2} \mathrm{H}$ and $\delta^{18} 0$ analyses are available and two of them suggest rainwater recharge during a glacial period. Groundwater at the six sampled deep, confined aquifers is thus 'old', with values below 10 PMC. Comparable corrected ages were determined for groundwater in the Eocene aquifer in northwestern Flanders (Blaser et al., 2010), which is the extension of the Palaeogene aquifers in Zeeland.

\section{Shallow, semi-confined aquifers}

Figure 3 shows plots of the chloride vs sodium concentration for the shallow, semi-confined aquifers, where the seawater composition is indicated as reference. The $\mathrm{Cl}$ concentrations range from around $10 \mathrm{mgl}^{-1}$ to $15,000 \mathrm{mgl}^{-1}$ (except for one outlier of $24,800 \mathrm{mgl}^{-1}$ in Carboniferous rock in south Limburg): i.e. the chloride concentrations are lower than in seawater $\left(19,000 \mathrm{mg} \mathrm{l}^{-1}\right)$. Fresh groundwater may thus be present when the pre-Neogene units lie within a few hundreds of metres below the surface, which can be related to infiltration of rainwater in outcrop areas or in the permeable units overlying them (Glasbergen, 1981). This is evidenced for groundwater in the Belgian Kempen by the presence of tritium (Beaucaire et al., 2000). It is further illustrated in Figure 4 for groundwater in the Carboniferous unit in southern Limburg, where two groundwater types can be discerned: a shallower, fresh one and a deeper, saline one. Note that this area has been free of 
Table 3. Groundwater analyses ( $m g l^{-1}$, except when stated otherwise) for samples from buried aquifers and the reservoirs in South-Holland that may include isotope analysis, plus the reference for groundwater close to rock salt in Gorleben, Germany (Kimpe, 1963; Glasbergen, 1981, 1984, 1985; Van der Weiden, 1983; Heederik, 1989; Eggenkamp, 1994; Kloppmann et al., 2001; Griffioen, 2015).

\begin{tabular}{|c|c|c|c|c|c|c|c|c|c|c|c|}
\hline $\begin{array}{l}\text { Sample } \\
\text { Location } \\
\text { Geology }\end{array}$ & $\begin{array}{c}\text { B08D0034 } \\
\text { Nieuweschans } \\
\text { Palaeogene }\end{array}$ & $\begin{array}{c}\text { B49F1427 } \\
\text { Zegge } \\
\text { Palaeogene }\end{array}$ & $\begin{array}{l}\text { B50H0373 } \\
\text { Maarle } \\
\text { Palaeogene }\end{array}$ & $\begin{array}{c}\text { B52E0114 } \\
\text { Broekhuizenvorst } \\
\text { Palaeogene }\end{array}$ & $\begin{array}{c}\text { B52C0234 } \\
\text { Asten } \\
\text { Palaeogene }\end{array}$ & $\begin{array}{c}\text { Central } \\
\text { Limburg } \\
\text { Palaeogene }\end{array}$ & $\begin{array}{c}\text { 61F296 } \\
\text { Maastricht } \\
\text { Carboniferous }\end{array}$ & $\begin{array}{c}\text { 61F296 } \\
\text { Maastricht } \\
\text { Upper Devonian }\end{array}$ & $\begin{array}{c}\text { DeLier 23A } \\
\text { South-Holland } \\
\text { Early Cretaceous }\end{array}$ & $\begin{array}{c}\text { Wassenaar } 27 \\
\text { South-Holland } \\
\text { Early Cretaceous }\end{array}$ & $\begin{array}{c}\text { GoHy674 } \\
\text { Gorleben (D) }\end{array}$ \\
\hline Depth(m b.s.l.) & 582 & 412 & 494.5 & 539 & 1520 & $480-650$ & $230-240$ & $460-480$ & $1733-1789$ & $1310-1316$ & 208 \\
\hline $\mathrm{pH}$ & 6.51 & 7.36 & 7.42 & 6.64 & 5.8 & $7.2 / 8.6$ & 7.33 & 7.10 & & & 7.1 \\
\hline $\mathrm{Na}$ & 43,500 & 7595 & 5967 & 7200 & 16,769 & $1000 / 4175$ & 750 & 3600 & 31,879 & 30,312 & 126,000 \\
\hline $\mathrm{Ca}$ & 1250 & 317 & 147 & 610 & 1400 & $20 / 146$ & 61 & 170 & 3419 & 3977 & 1240 \\
\hline $\mathrm{Mg}$ & 950 & 344 & 160 & 290 & 599 & $17 / 135$ & 29 & 82 & 727 & 859 & 1210 \\
\hline $\mathrm{Li}$ & 4.6 & 1.26 & 0.73 & & 3.1 & & 1.35 & 5.3 & 0.745 & $<$ det. limit & 0.23 \\
\hline $\mathrm{Cl}$ & 71,500 & 12,321 & 9211 & 12,939 & 31,500 & 1078 / 6913 & 984 & 5300 & 57,830 & 56,600 & 192,000 \\
\hline $\mathrm{Br}$ & 140 & 41.7 & 30.5 & 20.2 & 100 & & 1.78 & 8.73 & & & \\
\hline $\mathrm{SO}_{4}$ & 1800 & 613 & 153 & 230 & $<0.23$ & 14.4 / 144 & 36 & 83 & 75 & 90 & 5600 \\
\hline Alkalinity & 183 & $1087^{\mathrm{a}}$ & $1182^{\mathrm{a}}$ & 514 & 44 & 232 / 964 & 595 & 852 & 230 & 90 & 135 \\
\hline B & & & & & 42.0 & & & & 39.2 & 25.5 & 4.84 \\
\hline$\delta^{18} 0(\%)$ & $-3.23 /-3.15$ & & & $-6.52 /-6.25$ & & & -8.90 & -8.20 & -2.9 & --3.5 & -8.8 \\
\hline$\delta^{2} \mathrm{H}(\%)$ & $-24.2 /-25.6$ & & & $-44.5 /-39.5$ & & & -58.0 & -56.2 & -24 & -25 & -60 \\
\hline$\delta^{37} \mathrm{Cl}(\%)$ & & & & & & & & & -1.12 & -0.73 & \\
\hline${ }^{14} \mathrm{C}$ act. (PMC) & 9 & $<2$ & $<2$ & $1 / 3.4$ & 3 & & 0.4 & 3.0 & & & \\
\hline Calcite & -0.01 & 0.74 & 0.66 & 0.12 & -1.19 & $-0.11 / 0.80$ & 0.10 & -0.43 & & & 1.62 \\
\hline Dolomite & 0.21 & 1.88 & 1.74 & 0.33 & -2.14 & 0.17 / 1.91 & 0.13 & -0.90 & & & 4.02 \\
\hline Anhydrite & -0.45 & -1.39 & -2.20 & -1.52 & -4.32 & $-3.10 /-2.31$ & -2.12 & -1.67 & -1.01 & -1.21 & 1.08 \\
\hline Halite & -1.17 & -2.83 & -3.05 & -2.84 & -2.18 & $-4.32 /-3.32$ & -4.77 & -3.47 & -1.50 & -1.53 & 0.42 \\
\hline Log $P_{\mathrm{C} 02}$ & -1.56 & -1.44 & -1.49 & -1.10 & -1.22 & $-2.41 /-1.71$ & -1.66 & -1.28 & & & -2.25 \\
\hline
\end{tabular}

${ }^{a}$ Calculated from electroneutrality. 

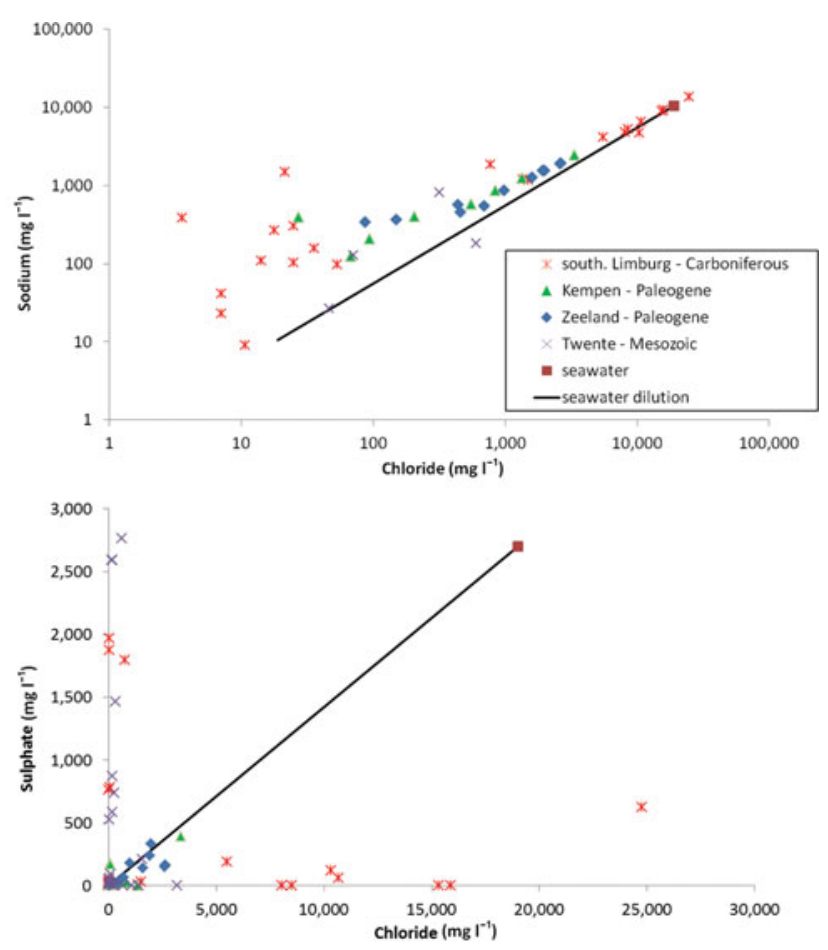

Fig. 3. Concentration plots of the compounds $\mathrm{Na}$ (above) and $\mathrm{SO}_{4}$ (below) vs $\mathrm{Cl}$ for groundwater in the shallow, semi-confined aquifers. Note the different kinds of scale axes. See Figure 1 for a map with the geographical names used.

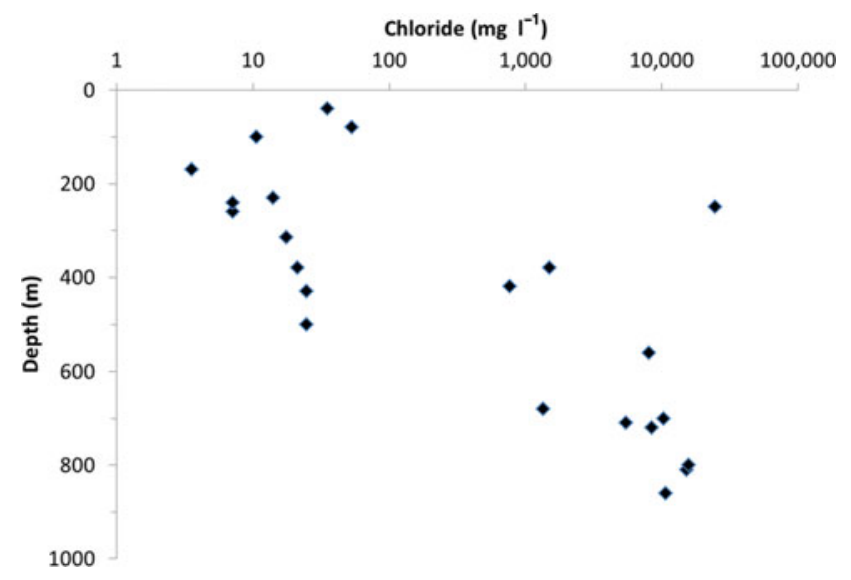

Fig. 4. Chloride concentration vs depth for groundwater in the Carboniferous aquifer in the coal-mining district of southern Limburg (data obtained from Kimpe, 1963).

seawater influence since at least the Pliocene, i.e. for at least $5 \mathrm{Ma}$. The $\mathrm{Cl}$ concentrations for the four Belgian wells in the Palaeogene aquifer and close to the Belgian/Dutch border vary considerably - from 95 to $3357 \mathrm{mgl}^{-1}$ - which implies that the fresh/saline interface in groundwater immediately below the Rupel Clay does not coincide with this border.

Many samples plot above the seawater dilution line, which implies that they are enriched in Na relative to $\mathrm{Cl}$ (Fig. 3). This is probably due to cation exchange under freshening conditions.

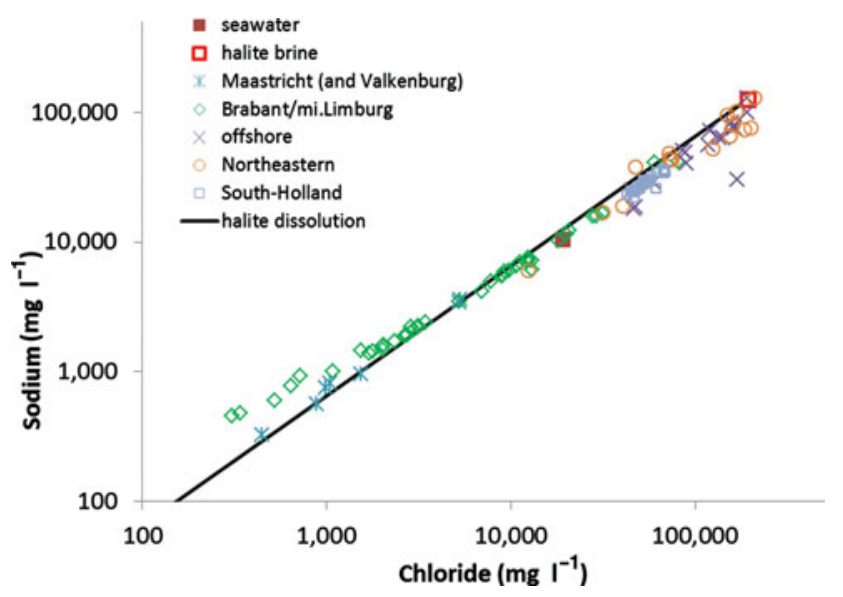

Fig. 5. Chloride vs sodium concentration plot for groundwater in deep, buried aquifers or oil and gas reservoirs (one fresh, relatively shallow sample from central Limburg lies outside the graph).

Fresh or brackish samples $\left(\mathrm{Cl}<1000 \mathrm{mgl}^{-1}\right)$ are also enriched in $\mathrm{K}$ and $\mathrm{Mg}$ (not shown), which provides further evidence for freshening of the aquifers. However, the saline samples $(\mathrm{Cl}>$ $1000 \mathrm{mg} \mathrm{l}^{-1}$ ) are depleted in $\mathrm{Mg}$, and the underlying reason is not obvious. They are also depleted in $\mathrm{SO}_{4}$, which indicates sulphate reduction. Conversely, the fresh samples are enriched in $\mathrm{SO}_{4}$ up to $2766 \mathrm{mgl}^{-1}$, which indicates pyrite oxidation in open-air conditions and/or dissolution of gypsum or anhydrite (which are commonly found in Dutch, Cretaceous and older formations; Wong et al., 2007). The fresh $\mathrm{SO}_{4}$-rich samples were from the Limburg mining district or Twente.

\section{Buried, confined aquifers}

Generally, samples from the buried, confined aquifers have higher ranges in concentrations for the main ions than those from the shallow, semi-confined ones, but lower ranges than those from the reservoirs (except alkalinity; Table 2). Figure 5 shows chloride vs sodium concentration for the buried aquifers as well as for the reservoirs. Both the seawater composition and brine as observed close to the Permian salt diapir in Gorleben, Germany (Kloppmann et al., 2001), are plotted as references. We chose the latter as reference for dissolution of halite ("halite brine') although it is unknown how representative this composition is for dissolution of rock salt in the Netherlands. For the deep, buried aquifers, the chemical data indicate that groundwater is usually saline, with $\mathrm{Cl}$ between 1000 and $32,000 \mathrm{mg} \mathrm{l}^{-1}$ (Table 2). However, exceptions occur towards brackish or hypersaline, reflecting inflow of meteoric groundwater on the one side and contact with brine or rock salt on the other. In such cases, the highest $\mathrm{Cl}$ concentration exceeds the seawater concentration by less than a factor 2 and the lowest concentration no longer refers to brackish water.

Several relatively extensive analyses including isotopes are available for groundwater in buried, deep aquifers (Table 3; 

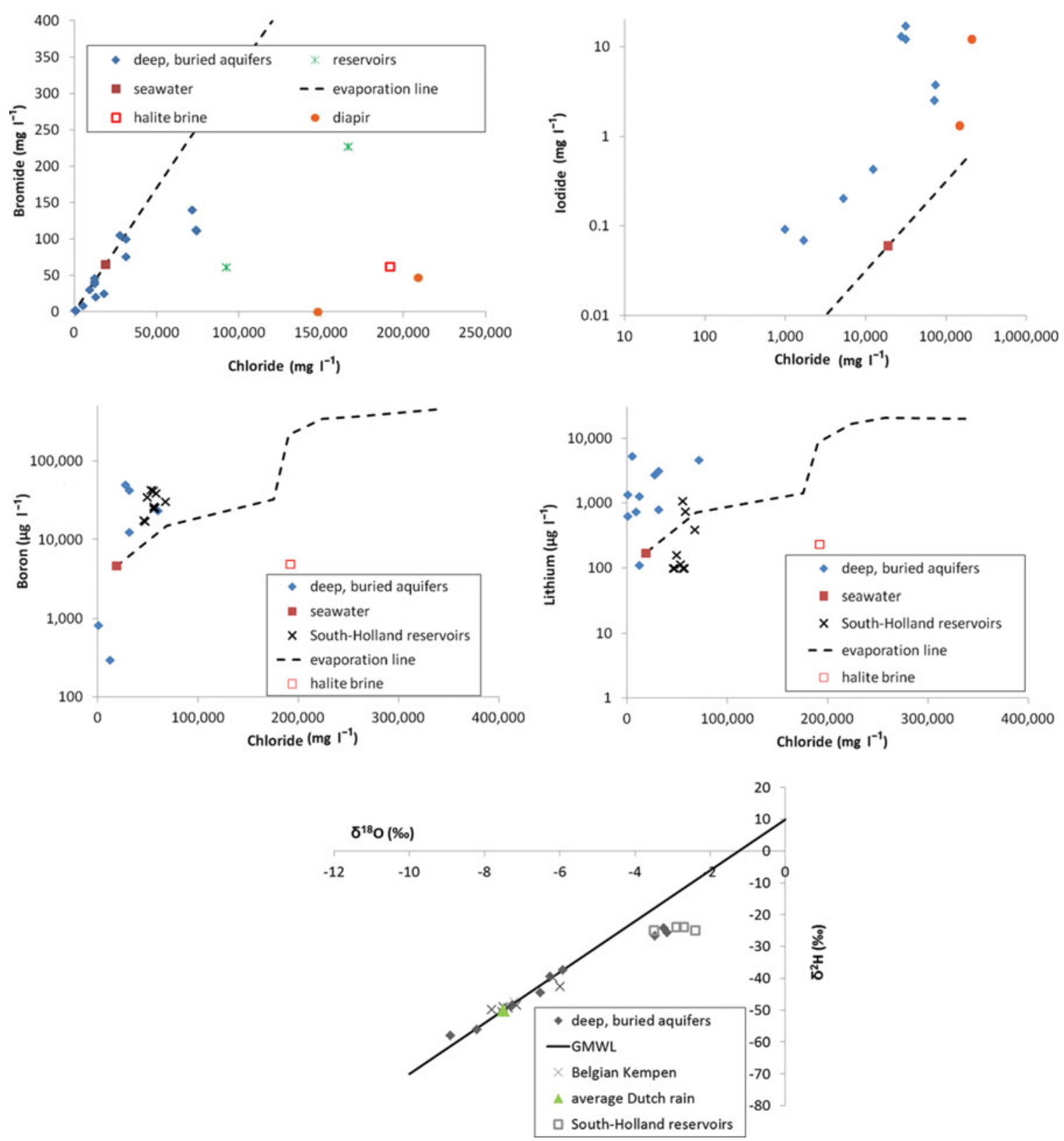

Fig. 6. Bromide, $L i, I$ and $B$ concentrations vs chloride as present for a limited series of samples together with the results of isotope analysis of $\mathrm{H}_{2} \mathrm{O}$ in some saline samples (the average for Dutch rainwater is shown for comparison, and GMWL stands for global meteoric water line). Samples with $100 \mu \mathrm{g} \mathrm{Li}^{-1} \mathrm{refer}$ to analyses below detection limit, which must be $100 \mu \mathrm{gl}^{-1}$ or smaller. Seawater evaporation pathways according to data from Fontes \& Matray (1993a).

Fig. 6). A mixture of rainwater and seawater is indicated for the two aquifer samples from Nieuweschans, where the $\delta^{18} 0$ and $\delta^{2} \mathrm{H}$ values indicate that the fraction of rainwater varied from one-third to almost half. The other samples lie on the global meteoric water line (GMWL). Based on the few $\delta^{2} \mathrm{H}$ and $\delta^{18} 0$ isotope analyses (Fig. 6), it has been concluded (Glasbergen, 1984, 1985) that the origin of groundwater in these samples varies from rainwater infiltrated during a glacial period (at Maastricht), recent rainwater (at Broekhuizenvorst) and a mixture of rainwater and seawater (at Nieuweschans). For the latter, hydrological contact with a salt dome - and possibly evaporation too - also plays a role. For comparison, the isotope analyses for the Belgian semi-confined Palaeogene groundwater samples indicate a rainwater origin.

Few data on $\mathrm{Br}$ are present for the regular groundwater aquifers that do not serve as oil and gas reservoirs. The available $\mathrm{Cl} / \mathrm{Br}$ data show that a series of Dutch samples lies on the seawater evaporation/dilution line (Fig. 6), including the two samples from the deep drilling in Asten that have $\mathrm{Cl}$ concentrations above that of seawater (and around $100 \mathrm{mgBr}^{-1}$ ). This implies evaporation of seawater prior to infiltration. The samples from the Belgian Palaeogene aquifers lie on this line, too. The samples from the former Oranje Nassau 1 mine, Broekhuizenvorst, Nieuweschans and Arcen deviate markedly from the $\mathrm{Cl} / \mathrm{Br}$ 
seawater ratio and maybe so do the two samples from Maastricht that have the lowest $\mathrm{Cl}$ concentrations of this subseries. This being the case, the $\mathrm{Br}$ concentration of $140 \mathrm{mgl}^{-1}$ vs the $\mathrm{Cl}$ concentration of $71,500 \mathrm{mg} \mathrm{l}^{-1}$ for Nieuweschans is remarkable. The saline nature of this groundwater just below the Rupel Clay in the Dongen aquifer at $582 \mathrm{~m}$ depth has been attributed to rock salt dissolution (Glasbergen, 1981). This should normally yield a lower Br concentration, as indicated by the halite brine reference and two Dutch samples from diapirs (Fig. 6): possible explanations for this, in addition to an analytical error, are dissolution in evaporated seawater or local presence of Br-containing salt that typically precipitates in the last evaporative stages. The isotopic data of $\delta^{2} \mathrm{H}$ (around -25\%) and $\delta^{18} 0$ (around $-3 \%$ ) suggest a mixture of seawater and rainwater. An enrichment in $\mathrm{Br}$ relative to $\mathrm{Cl}$ can be explained by mixing with a residual brine, but these isotopic data make it unlikely that mixing with a residual brine from which halite has precipitated plays a role. So does the palaeohydrological evolution of the Palaeogene aquifer from which this sample is collected. The sample from Broekhuizenvorst lies on the GMWL but not on the $\mathrm{Cl} / \mathrm{Br}$ evaporation line, so, based on these similar lines of evidence, the high salinity of this sample must be attributed to rock salt (note that Broekhuizenvorst lies along the Meuse River in the southern part of the Netherlands). A similar explanation may hold for the other samples that deviate from the $\mathrm{Cl} / \mathrm{Br}$ seawater ratio and are also located in the southern Netherlands.

Boron and lithium can also be useful tracers to characterise whether mixing with residual brine or dissolution of rock salt affects the groundwater composition. Figure 6 shows plots of the limited series of $\mathrm{Li}$ and $\mathrm{B}$ analyses vs $\mathrm{Cl}$; Tables 2 and 3 provide specific data. The seawater evaporation line is also plotted where the evolution beyond halite precipitation is also depicted (as provided by Fontes \& Matray, 1993a): a brine becomes enriched in these two species relative to $\mathrm{Cl}$ as soon as halite precipitates due to subaerial evaporation. The data for the buried aquifers show that most samples lie above the seawater evaporation/dilution line. This suggests in the first instance that mixing with residual brines plays a role. However, some of the samples are so much enriched that they lie above any mixing line irrespective of which evaporative stage is considered for the residual brine. This holds in particular for the samples from Asten that contain 42,000-50,000 $\mu \mathrm{g} \mathrm{Bl}^{-1}$ and 2700-3000 $\mu \mathrm{g} \mathrm{Lil}^{-1}$ (Table 3 ). It is generally recognised that lithium and boron may be leached from the solid rock matrix, causing enrichment of these species above the seawater evaporation line in saline, subsurface waters (Collins, 1969; Giblin \& Dickson, 1992; Kharaka \& Hanor, 2004). Here, enhancement of temperature causes leaching of $\mathrm{Li}$ and $\mathrm{B}$ from rock as well as immobilisation processes for $B$. The samples from Asten have the largest sampling depth of $1600 \mathrm{~m}$ within the deep, buried aquifer group, and the high $\mathrm{Li}$ and B concentrations may thus be explained by the related, high temperature.
Close to 60 analyses that contain results on major ions on groundwater in buried aquifers were included in our dataset. Figure 5 shows that for this series, fresh groundwater is enriched in Na relative to $\mathrm{Cl}$, and the molar ratio is about 1 to 1 when $\mathrm{Cl}$ is between 2000 and $70,000 \mathrm{mgl}^{-1}$ and above this concentration may be depleted in $\mathrm{Na}$ relative to $\mathrm{Cl}$ for the samples from the reservoirs. Figure 7 shows concentration plots for four other main compounds vs Cl. Near-identical patterns are observed for $\mathrm{Ca}, \mathrm{Mg}$ and $\mathrm{K}$ in the buried aquifer samples: the data points lie above the seawater dilution line for fresh groundwater, and a near-linear pattern is observed up to $\mathrm{Cl}$ concentration of $70,000 \mathrm{mg} \mathrm{l}^{-1}$ that lies above (Ca) or between $(\mathrm{K}, \mathrm{Mg})$ the seawater evaporation line and the halite dissolution lines. The two most saline samples of the buried aquifer data group refer to samples from salt diapirs (Zuurdeeg et al., 1984): they lie below the seawater evaporation and halite dissolution lines, where the latter has the halite brine from Gorleben (Germany) as reference composition (Kloppmann et al., 2001).

A mixing line between fresh water and halite brine is also plotted in the log graphs for $\mathrm{K}$ and $\mathrm{Mg}$ (Fig. 7), where the fresh end-member contains $10 \mathrm{mg} \mathrm{l}^{-1}$ as reference concentrations for $\mathrm{Cl}, \mathrm{K}$ and $\mathrm{Mg}$. Most samples lie above this mixing line, too. When the brackish and saline samples are the result of mixing between fresh water and seawater (evaporated or not) or halite brine, these samples are thus enriched in $\mathrm{Na}$ and also in $\mathrm{Mg}$ and $\mathrm{K}$ when halite brine is assumed as end-member, but are mostly depleted in $\mathrm{Mg}$ and $\mathrm{K}$ when seawater is assumed as end-member. Enrichments of these cations can be attributed to cation-exchange or weathering processes; depletions are solely attributable to cation exchange, as dolomite precipitation and precipitation of K-bearing minerals is unlikely at the in situ temperatures of most buried aquifers sampled (mostly below $40^{\circ} \mathrm{C}$ ). The results for alkalinity and Ca suggest that cation exchange is an active process for these brackish and saline samples: Figure 8 illustrates that the alkalinity to Ca ratio on an equivalent basis is frequently substantially higher than 1 , i.e. the ratio cannot be explained by congruent dissolution of $\mathrm{Ca}$ carbonate by which similar equivalent concentrations of $\mathrm{Ca}^{2+}$ and $\mathrm{HCO}_{3}{ }^{-}$become produced. It is worth pointing out that the alkalinity is frequently several hundreds of $\mathrm{mgl}^{-1}$ in this data group and also in the shallow, semi-confined aquifer group (data not shown). As groundwater is usually saturated or supersaturated for calcite (Fig. 9) and the Lower Carboniferous, Cretaceous and Palaeogene aquifers are mostly marine, calcareous deposits, it is unrealistic to suppose that the concentrations of $\mathrm{Na}, \mathrm{K}, \mathrm{Mg}$ and $\mathrm{Ca}$ are controlled by silicate weathering where Ca silicates are barely present. Dissolution of gypsum or anhydrite, if present, is also unlikely as a control because $\mathrm{SO}_{4}$ is mostly diminished compared to the seawater ratio (Fig. 7) and additional $\mathrm{SO}_{4}$ reduction would not enhance the Ca concentration under Ca carbonate equilibrium. A combination of cation exchange and Ca carbonate precipitation/dissolution is more likely where the overall status is freshening. This may be less 

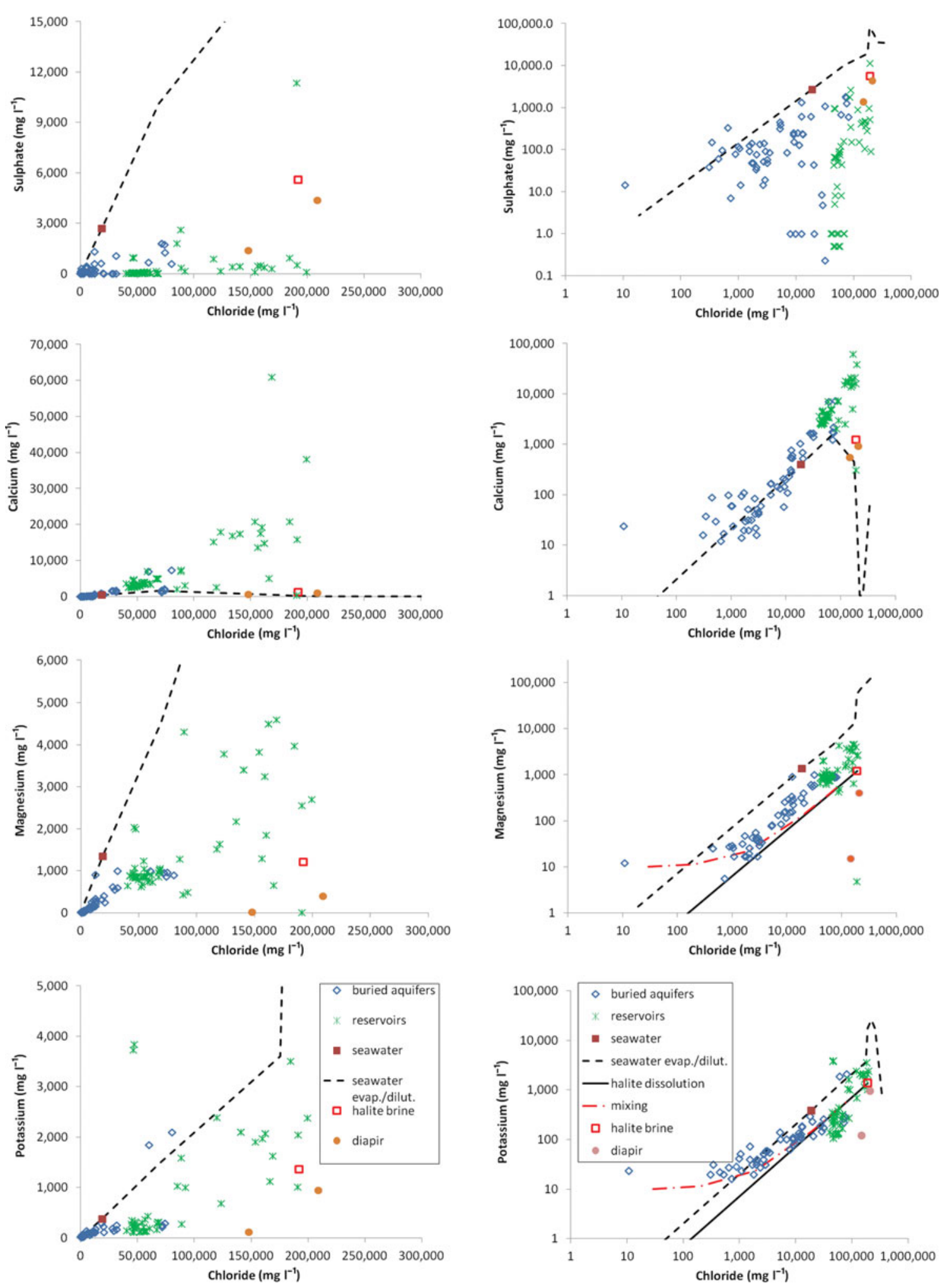

Fig. 7. Concentration plots of the main compounds $\mathrm{SO}_{4}, \mathrm{Ca}, \mathrm{Mg}$ and $\mathrm{K}$ vs $\mathrm{Cl}$ for samples from the deep, buried aquifers and the reservoirs at linear (left) and logarithmic scale (right). Seawater evaporation pathways according to data from Fontes \& Matray (1993a). The mixing line represents mixing between a freshwater type and halite brine. 
Fig. 8. Alkalinity to Ca ratio vs the $\mathrm{Cl}$ concentration for samples from the three data groups.

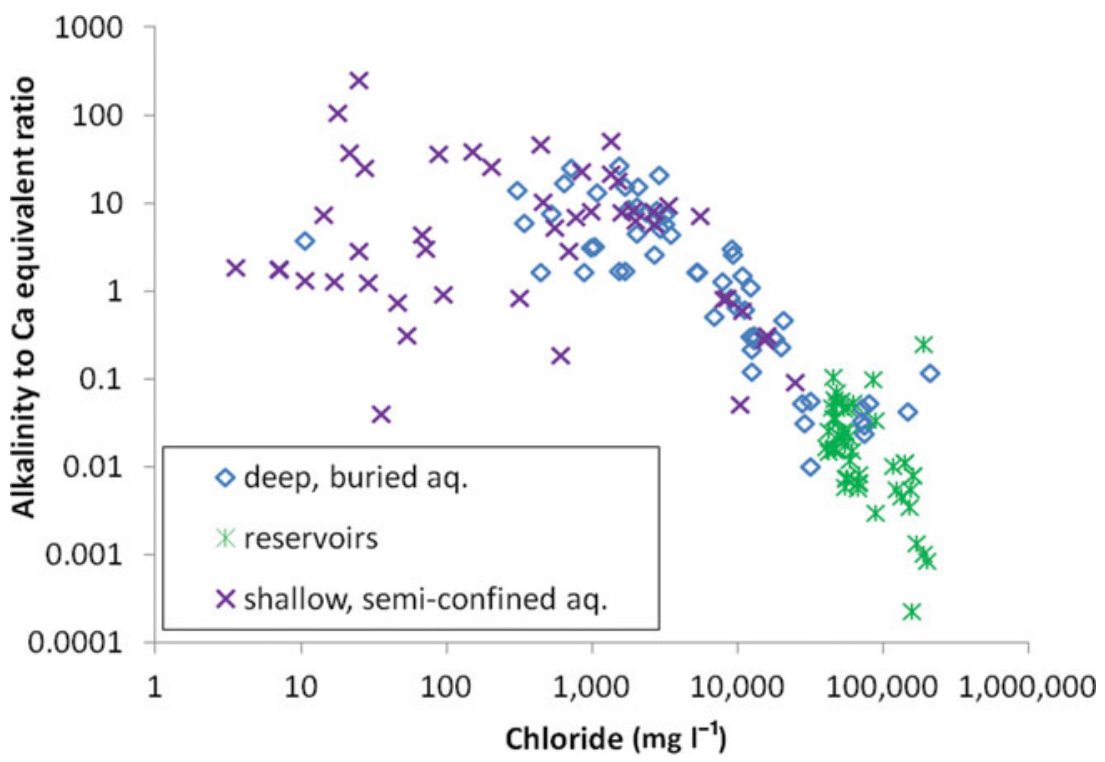

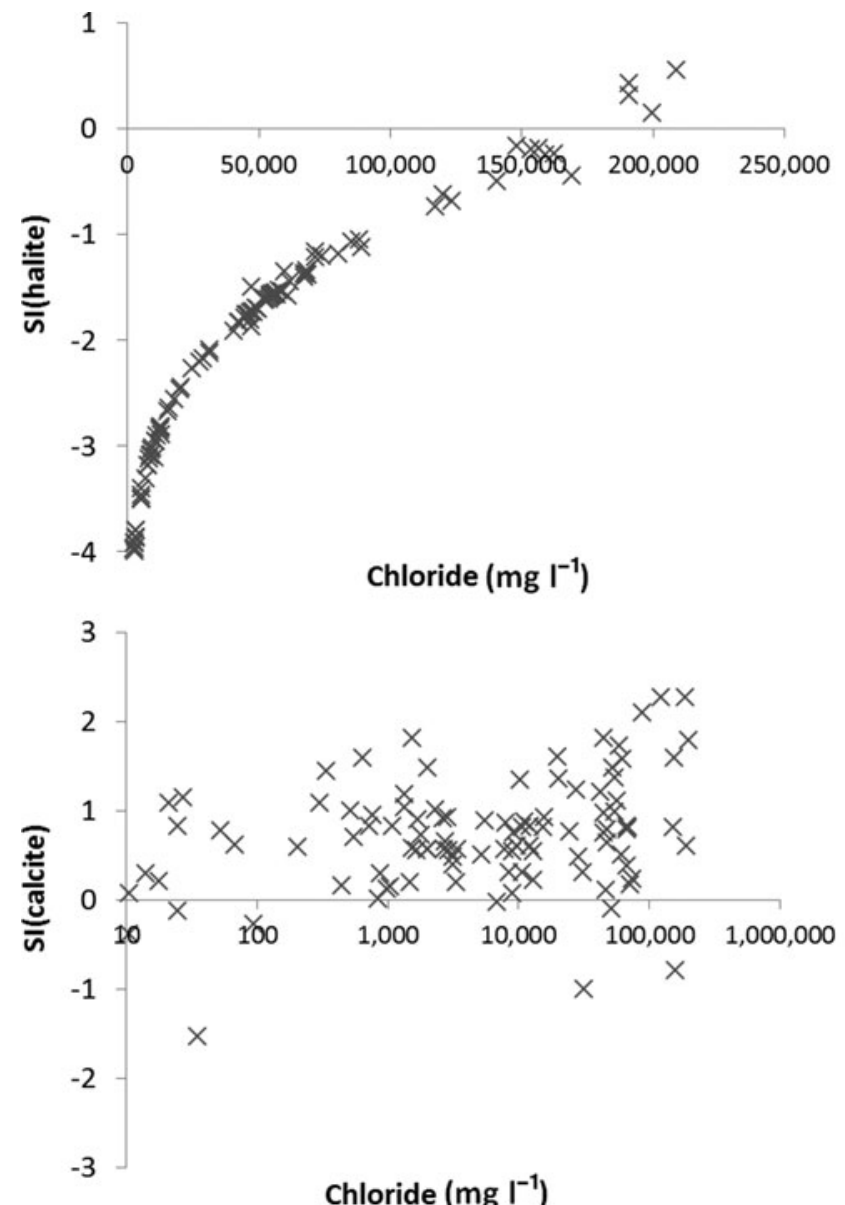

Chloride $\left(\mathrm{mg} \mathrm{I}^{-1}\right)$
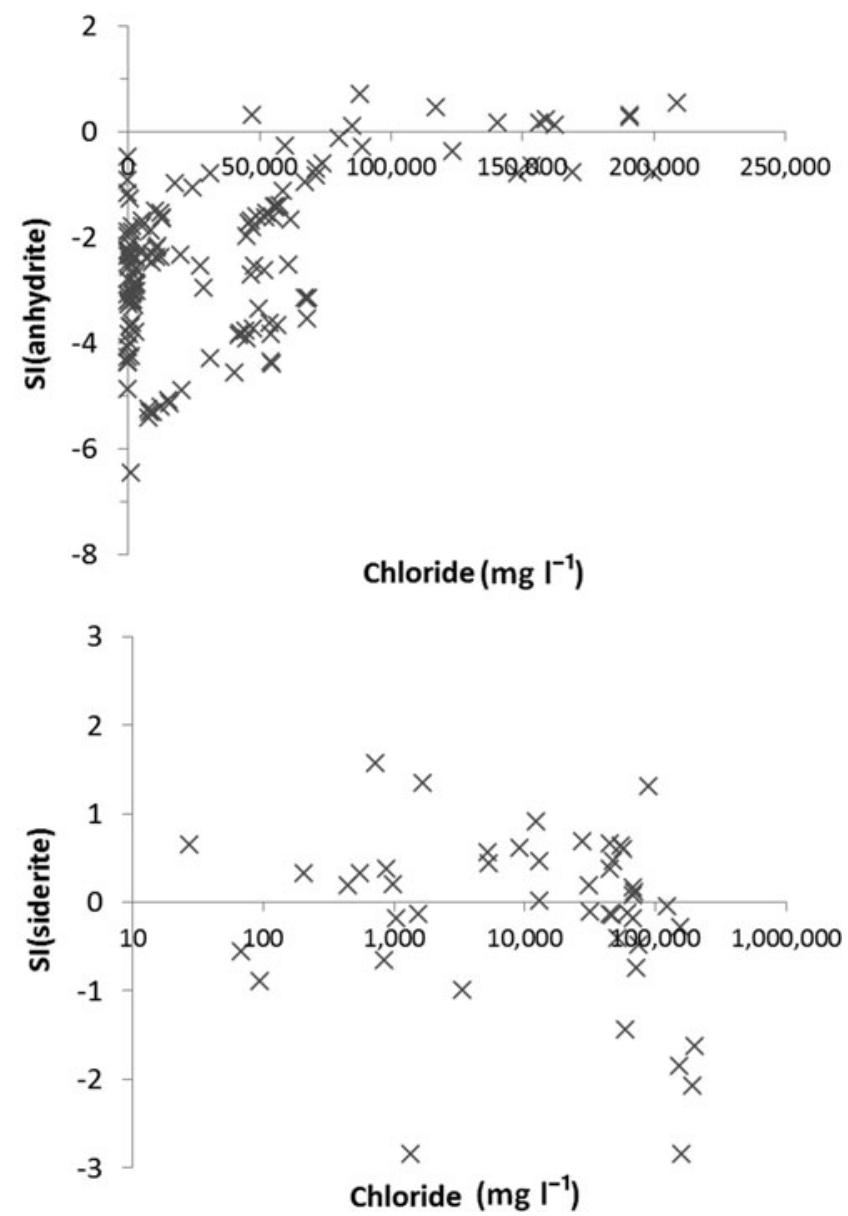

Fig. 9. Saturation indices of halite, anhydrite, calcite and siderite vs the $\mathrm{Cl}$ concentration of groundwater for samples from the three data groups. Note the different scales of the $\mathrm{x} / \mathrm{y}$-axes. 
self-evident for the lacustrine and fluvial Late Carboniferous rocks that also contain coal but that may be less carbonaterich. However, groundwater in the Carboniferous aquifers in south Limburg is mostly saturated in Ca carbonates and frequently has alkalinity to $\mathrm{Ca}$ equivalent ratios above 1.5 . This groundwater thus has no general characteristics that differ from those of the other aquifers. Except for the small series of samples discussed earlier, there is no evidence on whether mixing with seawater (evaporated or not) or dissolution of rock salt is the major process that determines the brackish or saline nature of many samples in the buried, confined aquifers. The $\mathrm{Cl}$ to $\mathrm{Br}$ ratio for the small series suggests that both processes may be operational in deep, pre-Neogene aquifers in the Netherlands.

\section{Oil and gas reservoirs}

Table 2 shows that the oil and gas reservoirs have the highest ranges in formation water concentrations for the main ions except for alkalinity. The chloride concentrations for the reservoirs are presented in Figure 5, plotted against the sodium concentrations. The reservoirs in South-Holland, Broad Fourteens Basin (which lies off the coast of North-Holland and is oriented southeast-northwest) and northeastern Netherlands have $\mathrm{Cl}$ concentrations above $40,000 \mathrm{mgl}^{-1}$, i.e. more than twice as high as in seawater. Water containing such high $\mathrm{Cl}$ concentrations will henceforth be referred to as hypersaline. The highest concentrations observed equal the $\mathrm{Cl}$ concentrations close to the salt dome in Gorleben. Groundwater having more than $85,000 \mathrm{mg} \mathrm{Cll}^{-1}$ has only been encountered in the reservoirs in the northeastern Netherlands and deep $(>2800 \mathrm{~m}$ ) reservoirs in Broad Fourteens Basin and Central Offshore Saddle. Exceptional samples from the Carboniferous Limestone Group at $1700 \mathrm{~m}$ depth in Merksplas and $2250 \mathrm{~m}$ depth in Turnhout (B), have 60,000 and $80,300 \mathrm{mg} \mathrm{Cll}^{-1}$, respectively. No such hypersaline water has been observed elsewhere in the southern part of the Netherlands, not even in the reservoirs at about 900-1800 m depth in South-Holland. These reservoirs have a typical Cl concentration of $42,000-62,000 \mathrm{mg} \mathrm{l}^{-1}$. Verweij (2003) attributed this to a combination of two reasons: (1) absence of major halite deposits in the southern part of the Netherlands and (2) meteoric flushing during Tertiary and Quaternary times. Permian Zechstein salt is the most widespread and thickest halite deposit in the Netherlands. It is found in the northern half of the Netherlands (Fig. 1; Geluk, 2007a). Halite deposits are also known for the Triassic Röt, Muschelkalk and Keuper Formations (Upper Germanic Trias Group) and Late Jurassic Weiteveen Formation (Schieland Group) (Geluk, 2007b). The distribution is most widespread for the Röt Formation and overlaps considerably with that of Zechstein salt. The Muschelkalk Evaporite Member also contains halite more southward than the Zechstein: local occurrences are found in the West Netherlands Basin and in the Roer Valley Graben. In Broad Fourteens Basin, hypersaline groundwater is observed in both the Permian Rotliegend deposits below and the Lower Triassic and Lower Cretaceous deposits above the Permian Zechstein evaporites. All wells in the Central Offshore Platform refer to the Rotliegend deposits below: one well has $45,000 \mathrm{mg} \mathrm{Cll}^{-1}$ and three others approximately $150,000 \mathrm{mg} \mathrm{Cll}^{-1}$.

Sulphate ranges from below detection limit to $2000 \mathrm{mg} \mathrm{l}^{-1}$, with one outlier. This outlier having $11,350 \mathrm{mg} \mathrm{SO}_{4} \mathrm{l}^{-1}$ may be meaningful, as the electroneutrality condition for this sample is better when this concentration is considered. Up to $70,000 \mathrm{mg} \mathrm{Cll}^{-1}$, groundwater is unsaturated for both anhydrite and gypsum (Fig. 9). Thus calcium sulphate precipitation does not control the $\mathrm{SO}_{4}$ concentration for these waters; the major influence is most likely reduction of $\mathrm{SO}_{4}$, combined with mineralisation of organic matter.

There are several tracers that may provide insight into the hydrogeological mechanism responsible for the brine compositions (e.g. Fontes \& Matray, 1993a, 1993b; Eastoe et al., 1999; Kharaka \& Hanor, 2004). The $\mathrm{Cl}$ to $\mathrm{Br}$ ratio may give a clue, because as a result of evaporation this is equal to the seawater weight ratio of 292 for brines, is lower for interstitial water when there has been precipitation of rock salt, and exceeds 1000 when natural rock salt has dissolved into flowing groundwater (Kloppmann et al., 2001). Kloppmann et al. (2001) observed $\mathrm{Br}$ concentrations of $55-65 \mathrm{mg} \mathrm{Br}^{-1}$ for brines having $182,000-192,000 \mathrm{mg} \mathrm{Cll}^{-1}$ in the vicinity of the Gorleben salt dome and around $20-25 \mathrm{mg} \mathrm{Br}^{-1}$ for brines having 40,000-65,000 $\mathrm{mg} \mathrm{Cll}^{-1}$. Two hypersaline Dutch samples from 'a salt diapir' fit into this picture, having $\mathrm{Cl}$ concentrations of 148,000 and $209,000 \mathrm{mgl}^{-1}$ (Fig. 6). Unfortunately, there are no data on $\mathrm{Br}$ for the brines in the oil and gas reservoirs except for wells Akkrum 13 in Friesland and Bergermeer 4 in NorthHolland (Fig. 6). Akkrum 13 is hypersaline, with a Br concentration between that of evaporated seawater and halite brine, and the Bergermeer 4 data suggest a straightforward mixture of seawater and halite brine. The $\mathrm{Cl}$ to $\mathrm{Br}$ ratio from these two samples gives no clues about the origin of the brines.

$\delta^{2} \mathrm{H}$ and $\delta^{18} 0$ isotopic analyses of formation water are present for only four samples from South-Holland (Fig. 6; Van der Weiden, 1983): the data vary around -3 for $\delta^{18} 0$ and -22 for $\delta^{2} \mathrm{H}$, which suggests a mixture of seawater and rainwater. These four samples have a $\mathrm{Cl}$ concentration close to $60,000 \mathrm{mg} \mathrm{l}^{-1}$. A third tracer is the isotopic ratio of stable $\mathrm{Cl}$ : the $\delta^{37} \mathrm{Cl}$ of rock salt at evaporation of $0.0 \%$ seawater varies between -0.5 and $+0.5 \%$, with the highest values associated with halite and the lower ones with other $\mathrm{K}$ and $\mathrm{Mg}$ salts (Eggenkamp et al., 1995; Eastoe et al., 2001). The related evaporated brine has $\delta^{37} \mathrm{Cl}$ values down to $-0.9 \%$, where such a value is associated with the last stage of evaporation and precipitating $\mathrm{K} / \mathrm{Mg}$ salts (Eggenkamp et al., 1995; Eastoe et al., 1999). Eggenkamp (1994) analysed eight samples that were studied by Van der Weiden (1983) too. Some samples were analysed for both $\mathrm{H}_{2} \mathrm{O}$ and $\mathrm{Cl}$ isotopes (cf. Table 3). The $\delta^{37} \mathrm{Cl}$ values vary between -1.77 and $-0.46 \%$, with a good positive correlation $\left(\mathrm{r}^{2}=0.89\right)$ with the $\mathrm{Cl}$ 
concentration for six samples from sandstones, while two samples from sand/shale beds lie below this regression line. Eggenkamp (1994) concluded that the samples formed by mixing of interstitial water from a source rock and aquifer water. This explanation does not hold for the two sand/shale samples, for which ultrafiltration or diffusion with related isotopic fractionation provides a better explanation. Many mixing scenarios can be established between seawater (evaporated or not), fresh meteoric water, dissolution of rock salt and diffusion, to explain the observations of the $\delta^{2} \mathrm{H}, \delta^{18} 0$ and $\delta^{37} \mathrm{Cl}$ tracers for these reservoir samples from South-Holland. Note that this group of samples lies below the halite dissolution line for $\mathrm{K}$ and between this line and the seawater evaporation line for $\mathrm{Mg}$. This might indicate that neither $\mathrm{KCl}$ salts nor evaporative brines play a role in their last stages, although $\mathrm{K}$ may also disappear in secondary reactions.

As discussed for the deep, buried aquifers, Li and B may also be useful tracers on the genesis of brines. Figure 6 shows their concentrations for ten samples from the South-Holland reservoirs and Tables 2 and 3 provide additional data. Unfortunately, no $\mathrm{Br}$ analysis was available for these samples. It is striking that, for $B$, the samples lie above the seawater evaporation line and, for $\mathrm{Li}$, they lie below (where the samples with $100 \mu \mathrm{gil}^{-1}$ actually refer to analyses below unknown detection limit, which must be $100 \mathrm{~g} \mathrm{gl}^{-1}$ or smaller based on other samples). This different behaviour implies that water-rock interactions play a role for at least one of these solutes. The highest B concentrations around 40,000 $\mathrm{g} \mathrm{l}^{-1}$ cannot be explained by mixing with any residual brine as $\mathrm{B}$ is too high for this compared to $\mathrm{Cl}$. Conversely, the lower Li concentration can be explained by mixing with a brine from halite dissolution.

Important types of palaeogroundwater flow in the reservoirs are induced by sedimentary loading and topography-driven flow (Verweij et al., 2003). Sedimentary loading will probably expel residual brines from the evaporite deposits, and topographydriven flow may introduce fresh groundwater in the reservoir's aquifer under palaeoenvironmental conditions. The palaeohydrological and diagenetic evolution of the reservoirs in the southern North Sea Basin is very complicated and varies among the individual sub-basins (Verweij et al., 2003, 2011; Gaupp \& Okkerman, 2011). Diagenetic evidence exists that meteoric water entered the Permian Rotliegend reservoir in the northern part of the Netherlands during the Early Cretaceous Period, giving rise to flushing of this aquifer (Lee et al., 1989). Palaeohydrological evidence also exists that topography-driven flow could reach great depths in the Triassic and Lower Cretaceous reservoirs above the Zechstein evaporites during the Late Cretaceous Period in the northern Broad Fourteens Basin (Bouw \& Oude Essink, 2003). There is also evidence that the Permian Rotliegend reservoir is overpressurised under present-day conditions, with the degree of overpressurisation increasing from southeast to northwest under the southern North Sea (Verweij et al., 2011). This suggests the presence of compaction-driven flow and absence of topography-driven flow under current conditions for this reservoir. The palaeo-fluid movements are difficult to reconstruct: the situation is further complicated by the influx of groundwater and hydrocarbons from the deeper Carboniferous formations during the palaeoenvironmental evolution of the Rotliegend reservoir (Gaupp \& Okkerman, 2011). Whether residual brine is still present in this reservoir under the Zechstein evaporites cannot be ascertained from the available hydrochemical data. Dissolution of rock salt together with fractionating diffusion, however, seems a plausible phenomenon for the South-Holland reservoirs above the Zechstein evaporites.

Figure 7 shows that the $\mathrm{Ca}$ concentrations outrange the $\mathrm{SO}_{4}$ concentrations by far for the most saline reservoir brines, when dissolution of gypsum or anhydrite as evaporites is assumed to be the principal source. The brines in the Broad Fourteens Basin usually have $43-2620 \mathrm{mg} \mathrm{SO}_{4} \mathrm{l}^{-1}$ (except for one outlier), whereas the brines in South-Holland repeatedly have $\mathrm{SO}_{4}$ below detection limit. It is also known that the natural gas may contain up to $7 \mathrm{ppm} \mathrm{H}_{2} \mathrm{~S}$ in the reservoirs in South-Holland (Core Lab, 1987). This means that the gas is not classified as sour (criterion $>1 \% \mathrm{H}_{2} \mathrm{~S}$; Lokhorst, 1998). With one exception, all $\mathrm{SO}_{4}$ concentrations in saline or hypersaline groundwater lie below those of the seawater and the halite brine: the groundwater is always depleted in $\mathrm{SO}_{4}$ by comparison with two endmember solutions, which is probably due to sulphate reduction and possibly anhydrite equilibrium for the reservoir formation waters having $\mathrm{Cl}$ above $100,000 \mathrm{mg} \mathrm{l}^{-1}$ (Fig. 9). The first process is mediated microbially below $80^{\circ} \mathrm{C}$ and thermochemically above $100^{\circ} \mathrm{C}$ or even $160^{\circ} \mathrm{C}$ (Machel, 2001). To reach $100^{\circ} \mathrm{C}$, the corresponding depth must be about $3 \mathrm{~km}$, assuming a thermal gradient of $30^{\circ} \mathrm{C} \mathrm{km}^{-1}$ (Verweij, 2003; Bonté et al., 2012). The gas and oil fields in South-Holland lie at a depth of 900-1800 m with corresponding temperatures around $30-60^{\circ} \mathrm{C}$. One may thus wonder whether thermochemical $\mathrm{SO}_{4}$ reduction could have played a role for these reservoirs, which would imply that the reduction of $\mathrm{SO}_{4}$ was microbially controlled or the pore water originates from deeper. Conversely, biodegraded oils are present in the Lower Cretaceous reservoirs of South-Holland due to tectonic inversion which brought these reservoirs close to the surface at the onset of the Palaeogene (De Jager \& Geluk, 2007), so microbial reduction of $\mathrm{SO}_{4}$ is plausible too.

Figure 7 also shows that the Ca concentrations are substantially higher than the $\mathrm{K}$ or $\mathrm{Mg}$ concentrations for the most saline groundwater in the reservoirs $\left(\mathrm{Cl}>100,000 \mathrm{mg} \mathrm{l}^{-1}\right)$ and also exceed by far the seawater and halite brine concentrations (except for one outlier). They generally increase with the $\mathrm{Cl}$ concentration. For $\mathrm{K}$, two clusters are found: one saline, which lies below the halite brine dissolution line and one hypersaline, which mostly lies between this line and the seawater evaporation line. With the exception of one outlier, the Mg concentrations also lie between these two lines. Most samples from the first cluster originate from the South-Holland reservoirs 
and those from the second originate mostly from the Broad Fourteens Basin.

Two mechanisms may give rise to brines in the oil and gas reservoirs of the North Sea Basin and elsewhere: mixing with connate water expelled from evaporites under compaction that had undergone evaporation beforehand ('residual brines') or dissolution of evaporite minerals such as rock salt. Egeberg \& Aagaard (1989) attributed the brines in oil fields on the Norwegian shelf to the former process, and Verweij (2003), following Hanor (1994), attributed the brines in the deeper Dutch subsurface to the latter. For deep groundwater (having $\mathrm{Cl}$ concentrations up to $30,000 \mathrm{mgl}^{-1}$ ) in Upper Cretaceous Chalk in Zealand (Denmark), Bonnesen et al. (2009) also deduced an origin from mixing between residual brine and meteoric water. An alternative explanation proposed by Worden et al. (2006) for the high $\mathrm{Cl}$ concentrations of around $120,000 \mathrm{mgl}^{-1}$ in a Triassic oil-bearing sandstone in the Wessex Basin (southern England) was dissolution of Upper Triassic evaporites. Both mechanisms thus seem operational in northwestern Europe.

The behaviour of $\mathrm{Ba}$ and $\mathrm{Sr}$ is also relevant in brines because barite $\left(\mathrm{BaSO}_{4}\right)$ may precipitate and contribute to the cementing of grains (Gluyas et al., 1997), with Sr co-precipitating, and diagenetic anhydrite may contain Ba and Sr (Purvis, 1992; Sullivan et al., 1994). Both cations have frequently been analysed in the hypersaline solutions, and concentrations range up to a few thousand $\mathrm{mgl}^{-1}$ for $\mathrm{Sr}$ and a few tens ofmg $\mathrm{l}^{-1}$ for $\mathrm{Ba}$ (except for one extreme of $250 \mathrm{mg} \mathrm{Ba}^{-1}$ ). Figure 10 shows the observed $\mathrm{Ba}$ and $\mathrm{Sr}$ concentrations plotted against $\mathrm{SO}_{4}$. An inverse relationship with a 1 to 1 slope at logarithmic scale can be recognised for the data points on the upper right-hand side. This could be indicative of an equilibrium relationship with a solubility control by $\mathrm{SO}_{4}$ minerals for these two divalent cations. Supersaturation for barite $\left(\mathrm{BaSO}_{4}\right)$ is usually found for saline or hypersaline groundwater, and for celestite, also for the hypersaline groundwater, but the saturation index of celestite varies from -3 to 1 for saline groundwater.

\section{Role of diagenesis in reservoirs}

The oil and gas reservoirs have undergone all kinds of diagenetic processes (Purvis, 1992; Gaupp \& Okkerman, 2011; Fischer et al., 2012), which are partly related to these reservoirs having higher temperatures than the younger, buried Palaeogene aquifers. Speciation calculations using PHREEQC (Parkhurst \& Appelo, 2013) indicate that only the most hypersaline solutions are supersaturated for halite (Fig. 9). This shows that the production of dissolved $\mathrm{Na}^{+}$and the immobilisation of $\mathrm{Na}^{+}$are spatially and temporally decoupled, because otherwise halite saturation could be maintained. The hypersaline groundwater is also saturated or supersaturated for anhydrite (Fig. 9; and also gypsum). Strong supersaturation with respect to calcite and dolomite is found for many samples, whereas the saturation state for siderite varies (Fig. 9). The calculation is,
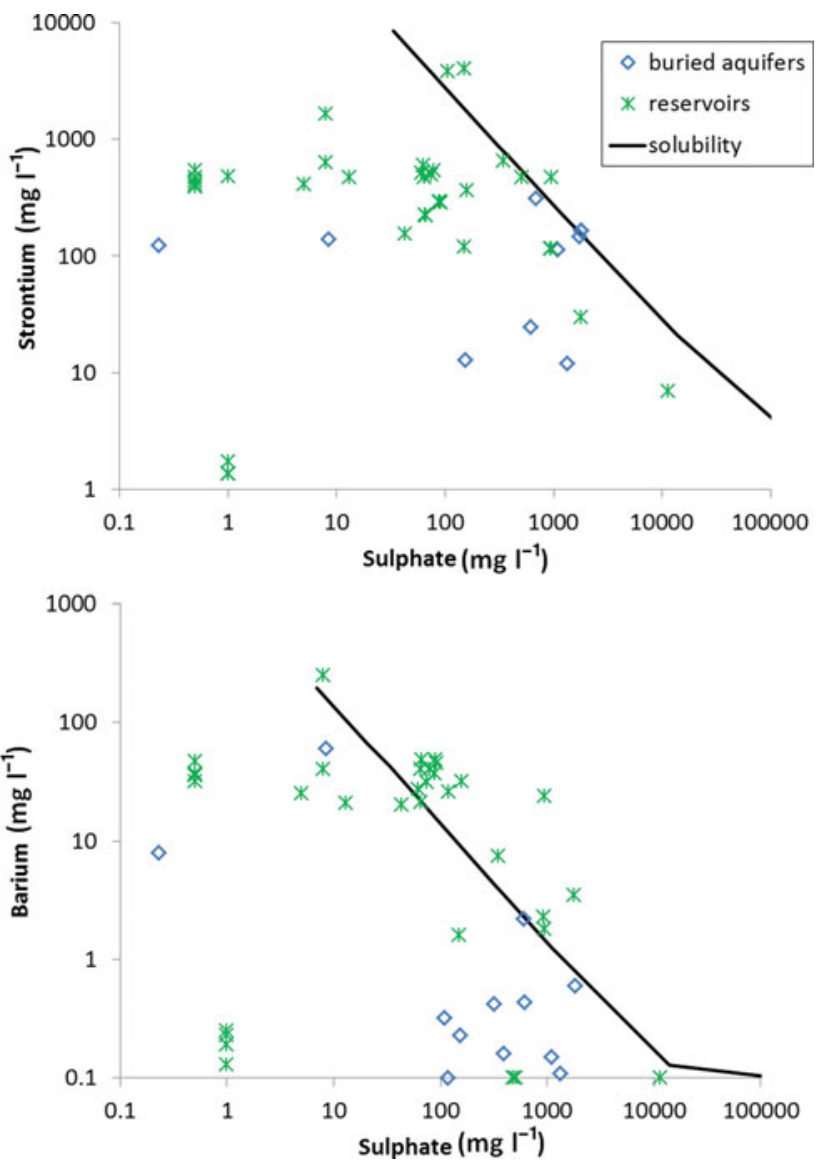

Fig. 10. Strontium (with solubility line for celestite; above) and $\mathrm{Ba}$ (with that for barite; below) concentrations vs the $\mathrm{SO}_{4}$ concentration for a limited series of samples from the deep, buried aquifers and the reservoirs.

however, probably imperfect, particularly due to sampling errors for $\mathrm{pH}$, shortcomings in the thermodynamic calculations and slight errors in the way temperature was estimated. Precipitation of siderite and calcite occurs under more variable geochemical conditions, including low temperatures. Precipitation of dolomite may play a role during diagenesis in the oiland gas-bearing formations such as the Rotliegend sandstone (Purvis, 1992; Gluyas et al., 1997; Gaupp \& Okkerman, 2011). This may influence the $\mathrm{Mg}$ concentration in addition to the $\mathrm{Ca}$ concentration. Dolomite precipitation is more unlikely in shallower groundwater aquifers, as dolomite precipitation is slow at low temperature whereas calcite precipitation is not, and supersaturation of both carbonates usually happens (Arvidson \& Mackenzie, 1999).

The more disperse concentration patterns for the four major cations above $85,000 \mathrm{mg} \mathrm{Cll}^{-1}$ by comparison with the patterns below $70,000 \mathrm{mg} \mathrm{l}^{-1}$ have been attributed to dissolution of halite with minor secondary reactions for $\mathrm{Na}$ below $70,000 \mathrm{mg}$ $\mathrm{Cll}^{-1}$ and important secondary reactions above. One mechanism that has been proposed (Land \& Prezbindowski, 1981; Egeberg \& Aagaard, 1989) is albitisation of Ca feldspars in the reservoirs 
containing NaCl brine:

$$
\begin{aligned}
& \mathrm{Na}^{+}+\mathrm{CaSi}_{2} \mathrm{Al}_{2} \mathrm{O}_{8}+\mathrm{H}_{4} \mathrm{SiO}_{4}+{ }_{1} / 2 \mathrm{H}^{+} \rightarrow \mathrm{NaSi}_{3} \mathrm{AlO}_{8}+\mathrm{Ca}^{2+} \\
& +2 \mathrm{H}_{2} \mathrm{O}+1 / 2 \mathrm{Al}_{2} \mathrm{O}_{3}+1 / 2 \mathrm{OH}^{-}
\end{aligned}
$$

where $\mathrm{Na}^{+}$originates from an evaporated seawater residue or dissolution of halite:

$$
\mathrm{NaCl} \rightarrow \mathrm{Na}^{+}+\mathrm{Cl}^{-}
$$

Egeberg \& Aagaard (1989) argued that transformation of K feldspar is unlikely both thermodynamically and in relation to the depletion of $\mathrm{K}$ below the seawater evaporation line. Illitisation of the reservoirs is commonly observed and the temperature under which illite formed varies strongly. The source of the K-bearing fluid is still uncertain (Gaupp \& Okkerman, 2011): both non-correlation between feldspar dissolution and amount of authigenic clay, and increasing feldspar dissolution in association with precipitation of illite and/or kaolinite have been observed. Zechstein rock salt has also been inferred to be the source of the $\mathrm{K}$ fluid.

Calcium concentrations above the seawater evaporation line are observed in our samples. Weathering of Ca feldspars may be a plausible explanation, although the Rotliegend Sandstone in the southern part of the North Sea Basin is usually poor in Ca feldspars but not in K feldspar (e.g. Purvis, 1992; Gluyas et al., 1997; Ziegler, 2006). Diagenetic overgrowths of $\mathrm{K}$ and $\mathrm{Na}$ feldspars are even found in this reservoir rock (Gaupp \& 0kkerman, 2011; Fischer et al., 2012). The Ca concentrations are not balanced by $\mathrm{SO}_{4}$ concentrations, which suggests in the first instance that neither gypsum nor anhydrite dissolution plays a role, whereas these evaporites are commonly found as precursors when halite as evaporite is also found. However, anaerobic oxidation of methane in association with $\mathrm{SO}_{4}$ reduction has been observed at elevated temperatures in hydrothermal systems (Holler et al., 2011; Biddle et al., 2012; Adams et al., 2013). These observations raise the question of whether transformation of anhydrite to calcite may happen in association with methane oxidation (Holler et al., 2011):

$$
\mathrm{CaSO}_{4}+\mathrm{CH}_{4} \rightarrow \mathrm{CaCO}_{3}+\mathrm{H}_{2} \mathrm{~S}+\mathrm{H}_{2} \mathrm{O}
$$

Preliminary modelling using PHREEQC showed that this process may give rise to water high in $\mathrm{Ca}$ and low in $\mathrm{SO}_{4}$, but there is no removal of $\mathrm{Na}$. It must also be remembered that anhydrite is found in the Rotliegend sandstone not only as an early-stage evaporite mineral but also as a late- or intermediate-stage diagenetic mineral (Purvis, 1992; Lanson et al., 1996; Gluyas et al., 1997; Gaupp \& 0kkerman, 2011). The environmental conditions for the intermediate diagenesis are, however, not clear: the effects of uplift or mixing of groundwater close to faults have not been elucidated. It is unknown whether conversion from calcite or aragonite to dolomite happened, which would not only explain enrichment of $\mathrm{Ca}$ above the seawater evaporation line but also depletion of $\mathrm{Mg}$ below. An entirely different explanation is that the seawater composition has varied over geological time, where it is, for example, assumed that Cretaceous seawater was enriched in $\mathrm{Ca}$ and depleted in $\mathrm{Na}, \mathrm{Mg}$ and $\mathrm{SO}_{4}$ relative to present-day seawater (Bonnesen et al., 2009).

\section{Trace element concentrations}

Iodine and selenium are interesting in the context of subsurface disposal of radioactive waste. All the data available on these two elements refer to the deep, buried aquifers. Our dataset contains only seven analyses for Se: five of them have a concentration below the detection limit of $1-2 \mu \mathrm{gl}^{-1}$; the other two also have concentrations below $1 \mu \mathrm{gl}^{-1}$, which is not far from the natural concentration in shallow groundwater and is below the seawater concentration (Table 4). Thus, little can be said about Se in aquifers of Oligocene and older age. Thirteen analyses are available for iodine, with most samples referring to hypersaline water and all samples plotting above the seawater I/Cl ratio (Fig. 6). The I concentration varies by two orders of magnitude and is roughly related to salinity. These groundwater samples are also enriched relative to the seawater ratio. The two groundwater samples from the Palaeogene Rupel and Cretaceous Houthem Formations at Asten show high concentrations above $10 \mathrm{mgl}^{-1}$. The other samples originate from the Palaeogene Dongen aquifer at Nieuweschans $\left(2.5 / 3.7 \mathrm{mg} \mathrm{l}^{-1}\right)$, the Carboniferous aquifers in Limburg $\left(0.07-1.3 \mathrm{mgl}^{-1}\right)$ and the salt diapirs $\left(1.3-12 \mathrm{mgl}^{-1}\right)$. It is generally accepted that iodine in groundwater mostly originates from degradation of predominantly marine plants, as the related organic compounds contain iodine, although the potential role of carbonates has often been overlooked (Heymann, 1925; Krul, 1933; Geirnaert, 1973; Claret et al., 2010; Li et al., 2014). The present observations confirm that in deep groundwater I is due more to mobilisation from the sediment than to a seawater origin, where marine sediments are often present in Palaeogene and older formations.

The number of analyses for other trace elements varies, with as many as 28 for Li. Most analyses refer to the deep, buried aquifers and for $\mathrm{Li}, \mathrm{Zn}, \mathrm{Cu}$ and B to reservoirs in South-Holland as well. Trace metals in groundwater are relevant with respect to environmental and human toxicity. Table 4 presents a statistical summary of the data. Considerable numbers of analyses lie below the detection limits, which sometimes vary considerably. The maximum concentrations observed are usually at least one order of magnitude larger than the related seawater concentrations, which can be up to 200 times higher (Se) than the Dutch background concentration limit for shallow, fresh groundwater or down to 50 times lower $(\mathrm{Cr}, \mathrm{Pb})$. Most remarkable are $\mathrm{Pb}$ and $\mathrm{Zn}$, which exceed the seawater concentration or national background concentration limit by more than a factor of 1000 . They are followed by $\mathrm{Cr}, \mathrm{Cu}$ and I. The median concentrations usually lie within a factor of 5 from both the national 
Table 4. Statistical data on concentrations $\left(\mu \mathrm{gl}^{-1}\right)$ of trace elements in groundwater of Oligocene and older formations in the Netherlands compared to seawater (as derived from Hem, 1970) and the Dutch natural background concentration limits for shallow groundwater (INS, 1997).

\begin{tabular}{|c|c|c|c|c|c|c|}
\hline Element & $\begin{array}{l}\text { Seawater } \\
\text { conc. }\end{array}$ & $\begin{array}{l}\text { National background } \\
\text { concentration limit }\end{array}$ & $\begin{array}{l}\text { Number of samples / } \\
\text { those below det. limit }\end{array}$ & $\begin{array}{l}\text { Median value } \\
(\text { for } n>5) \text { or } \\
\text { value }(n=1)\end{array}$ & $\begin{array}{l}\text { Min./max. } \\
\text { when above } \\
\text { det. limit }\end{array}$ & $\begin{array}{l}\text { Range in } \\
\text { det. limits }\end{array}$ \\
\hline $\mathrm{Ag}$ & 0.3 & & $2 / 2$ & & & $0.5 / 1$ \\
\hline $\mathrm{Al}$ & 10 & & $15 / 5$ & 5 & $1.3 / 10,000$ & $0.004 / 0.5$ \\
\hline As & 3 & 7 & $13 / 5$ & 1.5 & $1 / 2000$ & $0.5 / 5$ \\
\hline B & 4600 & & $16 / 0$ & 2600 & $0.3 / 50,050$ & \\
\hline $\mathrm{Be}$ & & 0.05 & $3 / 3$ & & & $0.342 / 0.5$ \\
\hline $\mathrm{Cd}$ & 0.11 & 0.06 & $14 / 8$ & $<0.1$ & $0.03 / 90$ & $0.07 / 5$ \\
\hline Co & 0.5 & 0.6 & $11 / 4$ & 2.1 & $0.267 / 24$ & $0.5 / 2$ \\
\hline $\mathrm{Cr}$ & 0.05 & 2.4 & $14 / 7$ & $<2$ & $0.017 / 1000$ & $0.314 / 2$ \\
\hline $\mathrm{Cu}$ & 3 & 1.3 & $23 / 15$ & $<$ d.l. $\$$ & 0.812 / 2041 & $2 / 500$ \\
\hline $\mathrm{F}$ & 1300 & & $11 / 1$ & 500 & $30 / 2200$ & 100 \\
\hline $\mathrm{Hg}$ & 0.03 & & $11 / 5$ & $<0.1$ & $0.1 / 1900$ & 0.1 \\
\hline I & 60 & & $13 / 1$ & 1900 & $69 / 17,000$ & 0.05 \\
\hline $\mathrm{Li}$ & 170 & & $28 / 6$ & 400 & $25 / 5300$ & 7 \\
\hline Mo & 10 & 0.7 & $3 / 1$ & & $9 / 340$ & 2 \\
\hline $\mathrm{Ni}$ & 2 & 2.1 & $14 / 5$ & $<5$ & $1 / 3000$ & $2 / 5$ \\
\hline $\mathrm{Pb}$ & 0.03 & 1.6 & $16 / 5$ & 2 & $0.3 / 108,000$ & $1 / 2$ \\
\hline $\mathrm{Rb}$ & 120 & & $1 / 0$ & 190 & & \\
\hline $\mathrm{Sb}$ & 0.5 & 0.09 & $5 / 2$ & & $0.29 / 3$ & 1 \\
\hline $\mathrm{Sc}$ & 0.04 & & $2 / 0$ & & $0.073 / 0.1$ & \\
\hline Se & 4 & 0.02 & $7 / 5$ & $<1$ & $0.064 / 0.387$ & $1 / 2$ \\
\hline Sn & 3 & $<2$ & $4 / 4$ & & & $1 / 5$ \\
\hline $\mathrm{Ti}$ & 1 & & $1 / 0$ & 5 & & \\
\hline $\mathrm{Tl}$ & & $<2$ & $3 / 1$ & & $0.096 / 0.156$ & 0.1 \\
\hline U & 3 & & $1 / 1$ & & & 0.2 \\
\hline V & 2 & 1.2 & $4 / 1$ & & $0.628 / 6$ & 2 \\
\hline $\mathrm{Zn}$ & 10 & 24 & $28 / 10$ & $15^{\$}$ & $10 / 147,000$ & $2 / 500$ \\
\hline
\end{tabular}

\$Van der Weiden (1983) did not provide a quantitative value for his detection limits; for Zn, neglecting these samples or assuming a detection limit below this median value yields a similar median value

background concentration limit and the seawater concentration. An exception is I, with a factor 30 above the seawater concentration. Lithium, boron and fluoride show high concentrations in an absolute sense, but this is common in seawater as well as in Dutch shallow saline groundwater of marine origin (Frapporti et al., 1996).

A comparison with other field studies on oilfield brines indicates that the medians in our data are similar to those found by Rittenhouse et al. (1969) for Co, Cr, Cu, Ni, Sn, Ti and V. Collins (1969) found higher maximum concentrations for Li and B concentrations, and Rittenhouse et al. (1969) found higher median concentrations for Li. Our maxima for $\mathrm{Pb}, \mathrm{Zn}$ and $\mathrm{Cu}$ (found in hypersaline reservoir samples) are extremely high, as Kharaka and Hanor (2004) state that the concentrations of heavy metals in oilfield waters are generally below $100 \mu \mathrm{gl}^{-1}$ because they are limited by the low solubilities of their respective sulphide minerals. These high concentrations are assumed to originate from redbed sands, which have a terrestrial origin and little reduced sulphur (Carpenter, 1989; Kharaka \& Hanor, 2004). Aqueous complexing of heavy metals with $\mathrm{Cl}$ may further raise the solubility of their sulphides. Coetsiers et al. (2009) present natural background concentrations for brackish and saline (Na $+\mathrm{Cl}>1000 \mathrm{mg} \mathrm{l}^{-1}$ ) groundwater in Eocene marine aquifers in Flanders, which are defined as the 90 -percentile value, i.e. close to the maximum concentration found. Their values lie within a factor 5 from our median values, except for $B$, which in their study is only $2.34 \mu \mathrm{gl}^{-1}$. Their 90 -percentile values are thus much lower than our maximum concentrations, whereas the deposits refer to comparable geological conditions. Conti et al. (2000) report high maximum concentrations for a few trace elements (As, Se, V, Sb) in saline groundwater originating from evaporated seawater trapped in the Late Messinian. 


\section{Conclusions}

We have given an overview of the composition of Dutch groundwater in Palaeogene and older formations by synthesising existing, published chemical analyses. The data refer to both groundwater aquifers and oil or gas reservoirs. These units lie below the geohydrological base level in most parts of the Netherlands. It appears that piezometric heads lie above the ground under natural conditions for these aquifers, and the oil and gas reservoirs are overpressurised. Advective flow is currently low or absent if the formations are deeply buried (>400 $\mathrm{m}$ depth).

The groundwater is generally saline or hypersaline. Chloride concentrations below $1000 \mathrm{mg} \mathrm{l}^{-1}$ are found down to a maximum of $500 \mathrm{~m}$ depth in Carboniferous to Palaeogene aquifers that lie near the eastern and southern borders of the Netherlands, where outcrops of these deposits are not far away. Chloride concentrations above the seawater concentration of $19,000 \mathrm{mg} \mathrm{l}^{-1}$ occur frequently in reservoirs and buried aquifers in the northern half of the Netherlands and less frequently in the southern half. The highly saline groundwater is related to the major occurrence of Permian and Triassic evaporite deposits in this part of the Netherlands. Due to the occurrence of salt diapirs, hypersaline groundwater can also be found in Palaeogene aquifers. Chloride concentrations of $100,000-200,000 \mathrm{mg} \mathrm{l}^{-1}$ have only been observed frequently in the Permian and Triassic reservoirs or at diapirs. Analyses that reveal insights into the hydrological and geochemical processes determining the salinity of groundwater are lacking for almost all the available data: better insights would be obtained if tracers such as $\mathrm{Br}$ and the isotopes $\delta^{2} \mathrm{H}-\mathrm{H}_{2} 0, \delta^{18} 0-\mathrm{H}_{2} \mathrm{O}$ and $\delta^{37} \mathrm{Cl}$ were analysed frequently. In general, it cannot be concluded with certainty whether the hypersaline reservoir waters originate from residual brines or dissolution of rock salt, but based on the few analyses of these tracers it seems plausible that the salinity in the South-Holland reservoirs is controlled by dissolution of rock salt plus diffusion. Some of the several saline samples from Palaeogene and older aquifers have a $\mathrm{Cl}$ to $\mathrm{Br}$ ratio that deviates from the seawater dilution/evaporation line, suggesting a contribution from rock salt dissolution, whereas some others do not deviate, suggesting a seawater origin for the high $\mathrm{Cl}$ concentration.

The $\mathrm{pH}$ is almost always near-neutral and the redox state is always anaerobic where there has often been extensive $\mathrm{SO}_{4}$ reduction. Most groundwaters are saturated or supersaturated in carbonates (but the values may be negatively influenced by erroneous $\mathrm{pH}$ measurement due to sampling limitations); anhydrite saturation occurs in hypersaline groundwater, and near-saturation in halite occurs when the $\mathrm{Cl}$ concentration is close to $200,000 \mathrm{mg} \mathrm{l}^{-1}$. The groundwater in the aquifers is usually freshening, as indicated by the ratios of $\mathrm{Na}$ to $\mathrm{Cl}$ and $\mathrm{Ca}$ to alkalinity. The few existing ${ }^{14} \mathrm{C}$ analyses indicate that groundwater from the buried aquifers has an apparent age exceeding 20,000 years.
Limited data are available for trace metals, with median values lying close to those for seawater and natural background concentrations; however, maximum concentrations can be up to three orders of magnitude higher. The iodide concentrations lie above the seawater ratio relative to $\mathrm{Cl}$, which implies that mobilisation has occurred due to degradation of organic matter of marine origin and/or the dissolution of carbonates.

\section{Acknowledgements}

The research leading to these results received funding from the Dutch research programme on geological disposal OPERA. OPERA is financed by the Dutch Ministry of Economic Affairs and the public limited liability company ElektriciteitsProduktiemaatschappij Zuid-Nederland (EPZ) and coordinated by COVRA. Three reviewers and the associate editor Dr M.E. Donselaar are thanked for their comments and suggestions that improved the manuscript. The language editor was J. Burrough.

\section{References}

Adams, M.M., Haorfrost, A.L., Bose, A., Joye, S.B. \& Girguis, P.R., 2013. Anaerobic oxidation of short-chain alkanes in hydrothermal sediments: potential influences on sulfur cycling and microbial diversity. Frontiers Microbiology 4: article 110.

Appelo, C.A.J., 2015. Principles, caveats and improvements in databases for calculating hydrogeochemical reactions in saline waters from 0 to $200^{\circ} \mathrm{C}$ and 1 to 1000 atm. Applied Geochemistry 55: 62-71.

Arvidson, R.S. \& Mackenzie, F.T., 1999. The dolomite problem: control of precipitation kinetics by temperature and saturation state. American Journal of Science 299: 257-288.

Beaucaire, C., Pitsch, H., Toulhoat, P., Motellier, S. \& Louvat, D., 2000. Regional fluid characterisation and modelling of water-rock equilibria in the Rupel Clay Formation and in the Rupelian aquifer at Mol, Belgium. Applied Geochemistry 15: $667-686$.

Bense, V.F., Van Balen, R.T. \& De Vries, J.J., 2003. The impact of faults on the hydrogeological conditions in the Roer Valley Rift System: an overview. Netherlands Journal of Geosciences 82: 41-54.

Biddle, J.F., Cardman, Z., Mendlovitz, H., Albert, D.B., Lloyd, K.G., Boetius, A. \& Teske, A., 2012. Anaerobic oxidation of methane at different temperature regimes in Guaymas Basin hydrothermal sediments. ISME Journal 6: 10181031.

Blaser, P.C., Coetsiers, M., Aeschbach-Hertig, W., Kipfer, R., Van Camp, M., Loosli, H.H. \& Walraevens, K., 2010. A new groundwater radiocarbon correction approach accounting for palaeoclimate conditions during recharge and hydrochemical evolution: the Ledo-Paniselian Aquifer, Belgium. Applied Geochemistry 25: 437-455.

Bless, M.J.M., 1981. De mineraalwaterboringen te Maastricht. Natuurhistorisch Museum Maastricht, 31 December: 32 pp.

Bonnesen, E.P., Larsen, F., Sonnenborg, T.O., Klitten, K. \& Stemmerik, L., 2009. Deep saltwater in Chalk of North-West Europe: origin, interface 
characteristics and development over geological time. Hydrogeology Journal 17: 1643-1663.

Bonté, D., Van Wees, J.D. \& Verweij, J.M., 2012. Surface temperature of the onshore Netherlands: new temperature dataset and modelling. Netherlands Journal of Geosciences 91: 491-515.

Bouw, L. \& Oude Essink, G.H.P., 2003. Fluid flow in the northern Broad Fourteens basin during Late Cretaceous inversion. Netherlands Journal of Geosciences 82: 55-69.

Caro Cuenca, M., 2012. Improving radar interferometry for monitoring faultrelated surface deformation. Applications for the Roer Valley Graben and coal mine induced displacements in the southern Netherlands. PhD Thesis. Delft University of Technology (Delft): $142 \mathrm{pp}$.

Carpenter, A.B., 1989. 0ccurrence of lead- and zinc-rich brine in the Rotliegendes Formation, the Netherlands. Abstracts with Program, Geological Society of America 21/6: A315.

Claret, F., Lerouge, C., Laurioux, T., Bizi, M., Conte, T., Ghestem, J.P., Wille, G., Sato, T., Gaucher, E.C., Giffaut, E. \& Tournassat, C., 2010. Natural iodine in a clay formation: implications for iodine fate in geological disposals. Geochimica Cosmochimica Acta 74: 16-29.

Clark, I. \& Fritz, P., 1997. Environmental isotopes in hydrogeology. Lewis Publications, Boca Raton, New York: 328 pp.

CMEO (Centrum voor Milieu-Effectonderzoek), 1991. MER NAM Waterinjectie in Zuidoost-Drenthe. TNO-CMEO (Delft), report.

Coenegracht, Y.M.A., Van Rooijen, P. \& Zuurdeeg, B.W., 1984. Het mineraalwater van Klein Vink, Arcen. Rijksuniversiteit Utrecht, afd. Geochemie, en Rijks Geologische Dienst (Utrecht): 49 pp.

Coetsiers, M., Blaser, P., Martens, K. \& Walraevens, K., 2009. Natural background levels and threshold values for groundwater in fluvial Pleistocene and Tertiary marine aquifers in Flanders, Belgium. Environmental Geology 57: $1155-1168$.

Collins, A.G., 1969. Chemistry of some Anadarko basin brines containing high concentrations of iodide. Chemical Geology 4: 169-187.

Conti, A., Sacchi, E., Chiarle, M., Martinelli, G. \& Zuppi, G.M., 2000. Geochemistry of the formation waters in the Po plain (Nothern Italy): an overview. Applied Geochemistry 15: 51-65.

Lab, Core, 1987. Wellsite sampling and analysis of produced water and gas. Field Ijsselmonde/Ridderkerk. Core Laboratories UK Ltd (Aberdeen).

Corona, F.V., 2005. Fault trap analysis of the Permian Rotliegend gas play, Lauwerszee Trough, NE Netherlands. 6th Petroleum Geology Conference, 6-9 0ctober 2003, London, UK: 327-335. Conference proceedings.

De Jager, J. \& Geluk, M.C., 2007. Petroleum geology. In: Th.E, Wong, D.A.J., Batjes \& J., de Jager (eds): Geology of the Netherlands. Royal Netherlands Academy of Arts and Sciences (Amsterdam): 241264.

De Mulder, E.F.J., Geluk, M.C., Ritsema, I., Westerhoff, W.E. \& Wong, T.E., 2003. De ondergrond van Nederland. TNO Nederlands Instituut voor Toegepaste Geowetenschappen/Wolters Noordhoff (Groningen): 379 pp.

De Vries, J.J., 2007. Groundwater. In: Wong, Th.E, Batjes, D.A.J. \& de Jager, J. (eds): Geology of the Netherlands. Royal Netherlands Academy of Arts and Sciences (Amsterdam): 295-315.

Dufour, F.C., 2000. Groundwater in the Netherlands. Facts and figures. TNO Netherlands Institute of Applied Geoscience (Delft/Utrecht): 96 pp.
Eastoe, C.J., Long, A. \& Knauth, L.P., 1999. Stable chlorine isotopes in the Palo Duto Basin, Texas: evidence for preservation of Permian evaporite brines. Geochimica Cosmochimica Acta 63: 1375-1382.

Eastoe, C.J., Long, A., Land, L.S. \& Kyle, J.R., 2001. Stable chlorine isotopes in halite and brine from the Gulf Coast Basin: brine genesis and evolution. Chemical Geology 176: 343-360.

Egeberg, P.K. \& Aagaard, P., 1989. Origin and evolution of formation waters from oil fields on the Norwegian shelf. Applied Geochemistry 4: 131142.

Eggenkamp, H.G.M., 1994. The geochemistry of chlorine isotopes. PhD Thesis. Utrecht University (Utrecht): $150 \mathrm{pp}$.

Eggenkamp, H.G.M., Kreulen, R. \& Koster van Gross, A.F., 1995. Chlorine stable isotope fractionation in evaporites. Geochimica Cosmochimica Acta 59: 51695175.

Fischer, C., Dunkl, I., Von Eynatten, H., Wijbrans, J.R. \& Gaupp, R., 2012. Products and timing of diagenetic processes in Upper Rotliegend sandstones from Bebertal (North German Basin, Parchim Formation, Flechtingen High, Germany). Geological Magazine 149: 827840.

Fontes, J.Ch. \& Matray, J.M., 1993a. Geochemistry and origin of formation brines from the Paris Basin, France. 1. Brines associated with Triassic salts. Chemical Geology 109: 149-175.

Fontes, J.Ch. \& Matray, J.M., 1993b. Geochemistry and origin of formation brines from the Paris Basin, France. 2. Saline solutions associated with oil fields. Chemical Geology 109: 177-200.

Frapporti, G., Vriend, S.P. \& Van Gaans, P.F.M., 1996. Trace elements in the shallow ground water of the Netherlands. A geochemical and statistical interpretation of the national monitoring network data. Aquatic Geochemistry 2: $51-80$.

Garavito Rojas, A.M.F., 2006. Chemical osmosis in clayey sediments. Field experiments and numerical modeling. PhD Thesis. Vrije Universiteit (Amsterdam): $140 \mathrm{pp}$.

Gaupp, R. \& Okkerman, J.A., 2011. Diagenesis and reservoir quality of Rotliegend sandstones in the northern Netherlands - A review. SEPM Special Publication 98: 193-226.

Geirnaert, W., 1973. The hydrogeology and hydrochemistry of the lower Rhine fluvial plain. Leidse Geologische Mededelingen 49: 59-84.

Geluk, M.C., 2007a. Perm. In: Wong, Th.E, Batjes, D.A.J. \& de Jager, J. (eds): Geology of the Netherlands. Royal Netherlands Academy of Arts and Sciences (Amsterdam): 63-83.

Geluk, M.C., 2007b. Triassic. In: Wong, Th.E, Batjes, D.A.J. \& de Jager, J. (eds): Geology of the Netherlands. Royal Netherlands Academy of Arts and Sciences (Amsterdam): 85-106.

Giblin, A.M., \& Dickson, B.L., 1992. Source, distribution and economic significance of trace elements in groundwaters from Lake Tyrrell, Victoria, Australia. Chemical Geology 96: 133-149.

Glasbergen, P., 1981. Extreme salt concentrations in deep aquifers in the Netherlands. Science of the Total Environment 21: 251-260.

Glasbergen, $\boldsymbol{P}_{\text {., }}$ 1984. Enkele voorbeelden van de grondwaterkwaliteit in paleogene watervoerende lagen. RIVM-mededeling 84-1: $31 \mathrm{pp}$.

Glasbergen, $\boldsymbol{P} ., 1985$. The origin of groundwater in Carboniferous and Devonian aquifers at Maastricht. Geologie en Mijnbouw 64: 123-129. 
Gluyas, J., Jolley, L. \& Primmer, T., 1997. Element mobility during diagenesis: sulphate cementation of Rotliegend sandstones, Southern North Sea. Marine and Petroleum Geology 14: 1001-1011.

Griffioen, J., 2015. The composition of deep groundwater in the Netherlands in relation to disposal of radioactive waste. TNO Geological Survey, report OPERA-PU-521TNO-2.

Grötsch, J. \& Gaupp, R. (eds) 2011. The Permian Rotliegend of the Netherlands. SEPM Special Publication N98: 375 pp.

Hanor, J.S., 1994. Physical and chemical controls on the composition of waters in sedimentary basins. Marine and Petroleum Geology 11: 31-45.

Heederik, J.P., 1989. Geothermal resources in the Central Graben area, the Netherlands. TNO - Dienst Grondwater Verkenning, report 0S89-18.

Hem, J.D., 1970. Study and interpretation of the chemical characteristics of natural water, 2nd edn. US Geological Survey Water-Supply Paper 1473: 363 pp.

Heymann, J.A., 1925. Het jodium in het waterleidingbedrijf. Water en Gas 9(4): 39-54.

Holler, T., Widdel, F., Knittel, K., Amann, R., Kellermann, M.Y., Hinrichs, K.U.

Teske, A., Boetius, A. \& Wegener, G., 2011. Thermophilic anaerobic oxidation of methane by marine microbial consortia. ISME Journal 5: 1946-1956.

INS, 1997. Integrale normstelling stoffen; milieukwaliteitsnormen bodem, water, lucht. Ministerie van Volkshuisvesting, Ruimtelijke Ordening en Milieu, Den Haag, VROM 97759/h-12-97.

Jongmans, W.J. \& Driessen, Cl.G., 1932. De mineraalwaterbron te Maastricht. Water 16(13): 137-145.

Keijzer, T.J.S., 2000. Chemical osmosis in natural clayey materials. PhD Thesis. Utrecht University (Utrecht): $166 \mathrm{pp}$.

Kharaka, Y.K. \& Hanor, J.S., 2004. Deep fluids in the continents: I. Sedimentary basins. In: Drever, J.I. (ed.): Treatise on geochemistry. Vol. 5. Surface and ground water, weathering, and soils. Elsevier (Amsterdam): 499-540.

Kimpe, W.F.M., 1963. Geochimie des eaux dans le houiller du Limbourg (PaysBas). Verhandelingen Koninklijk Nederlands Geologisch Mijnbouwkundig Genootschap, Geologie Serie 21: 25-45

Kloppmann, W., Négrel, Ph., Casanova, J., Klinge, H., Schelkes, K. \& Guerrot, C., 2001. Halite dissolution derived brines in the vicinity of a Permian salt dome (N German Basin). Evidence from boron, strontium, oxygen, and hydrogen isotopes. Geochimica Cosmochimica Acta 65: 4087-4101.

Kombrink, H., Doornenbal, J.C., Duin, E.J.T., Den Dulk, M., Van Gessel, S.F., Ten Veen, J.H. \& Witmans, N., 2012. New insights into the geological structure of the Netherlands; results of a detailed mapping project. Netherlands Journal of Geosciences 91: 419-446.

Krul, W.F.J.M., 1933. Het jodiumgehalte van het grondwater in verband met de hydrologische geschiedenis. De Ingenieur 25: A. 216-219.

Land, L.S. \& Prezbindowski, D.R., 1981. Chemical constraints and origin of four groups of Gulf Coast reservoir fluids: discussion. American Association of Petroleum Geology Bulletin 69: 119-121.

Lanson, B., Beaufort, D., Berger, G., Baradat, J. \& Lacharpagne, J.C., 1996. Illitization of diagenetic kaolinite-to-dickite conversion series: late-stage diagenesis of the Lower Permian Rotliegend sandstone reservoir, offshore of the Netherlands. Journal of Sedimentary Petrology 66: 501-518.

Lee, M., Aronson, J.L. \& Savin, S.M., 1989. Timing and conditions of Permian Rotliegende sandstone diagenesis, southern North Sea: $\mathrm{K} / \mathrm{Ar}$ and oxygen isotopic data. American Association of Petroleum Geology Bulletin 73: 195-213.
Li, J., Wang, Y., Guo, W., Xie, X., Zhang, L., Liu, Y. \& Kong, S., 2014. Iodine mobilization in groundwater system at Datong basin, China: evidence from hydrochemistry and fluorescence characteristics. Science of the Total Environment 468-469: 738-745.

Lokhorst, A. (ed.), 1998. The Northwest European Gas Atlas. Netherlands Institute of Applied Geoscience TNO (Haarlem).

Luijendijk, E., 2012. The role of fluid flow in the thermal history of sedimentary basins. Inferences from thermochronology and numerical modeling in the Roer Valley Graben, southern Netherlands. PhD Thesis. Vrije Universiteit (Amsterdam): $198 \mathrm{pp}$.

Machel, H.G., 2001. Bacterial and thermochemical sulfate reduction in diagenetic settings - old and new insights. Sedimentary Geology 140: 143-175.

Michon, L., Van Balen, R.T., Merle, O. \& Pagnier, H., 2003. The Cenozoic evolution of the Roer Valley Rift System integrated at a European scale. Tectonophysics 367: 101-126.

Nalpas, T., Le Douaran, S., Brun, J-P., Unternehr, P. \& Richert, J-P., 1995. Inversion of the Broad Fourteens Basin (offshore Netherlands), a small scale model investigation. Sedimentary Geology 95: 237-250.

Nelskamp, S., \& Verweij, J.M., 2012. Using basin modeling for geothermal energy exploration in the Netherlands - an example from the West Netherlands Basin and Roer Valley Graben. TN0 report TN0-060-UT-2012-00245: 113 pp.

Parkhurst, D.L. \& Appelo, C.A.J., 2013. Description of input and examples for PHREEQC Version 3 - a computer program for speciation, batch-reaction, onedimensional transport and inverse geochemical calculations. US Geological Survey Technical Methods Report, book 6, chapter A43: 497 pp.

Platt, J.D., 1994. Geochemical evolution of pore waters in the Rotliegend (Early Permian) of northern Germany. Marine and Petroleum Geology 11: 66-78.

Purvis, K., 1992. Lower Permian Rotliegend sandstones, southern North Sea: a case study of sandstone diagenesis in evaporite-associated sequences. Sedimentary Geology 77: 155-171.

Rittenhouse, G., Fulton III, R.B., Grabowski, R.J. \& Bernard, J.L., 1969. Minor elements in oil-field waters. Chemical Geology 4: 189-209.

Rowland, D., Koningsberger, E., Hefter, E. \& May, P.M., 2015. Aqueous electrolyte solution modelling: some limitations of the Pitzer equations. Applied Geochemistry 55: 170-183.

Smalley, P.C. \& Warren, E.A., 1994. North Sea formation waters: implications for diagenesis and production chemistry. Marine and Petroleum Geology 11: 2-4.

Stuurman, R.J., 2000. Transboundary hydrogeological processes in the southern Netherlands. Evaluation and protection of groundwater resources, IAH Conference, September 2000, Wageningen): 59-77. Conference proceedings.

Stuurman, R.J., 2004. Een verkenning naar de interactie tussen diep, paleogeen grondwater en ondiep grondwater in de provincie Noord-Brabant. TNO-NITG, report no. NITG 04-222-B0909: $76 \mathrm{pp}$.

Sullivan, M.D., Haszeldine, R.S., Boyce, A.J., Rogers, G. \& Fallick, A.E., 1994. Late anhydrite cement mark basin inversion: isotopic and formation water evidence, Rotliegend Sandstone, North Sea. Marine and Petroleum Geology 11: 46-54.

TNO, 1974. Grondwaterkaart van Nederland. Geohydrologische toelichting bij de kaartbladen 280ost Almelo, 29 Denekamp, 3400st Enschede, 35 Glanerbrug. Dienst grondwaterverkenning TN0 (Delft): $46 \mathrm{pp}$. and enclosures.

Van Adrichem Boogaert, H.A. \& Kouwe, W.F.P., 1997. Stratigraphic nomenclature of the Netherlands, revision and update by RGD and NOGEPA. Mededelingen Rijks Geologische Dienst no. 50, Delft/Haarlem, section I: 1-30. 
Van Balen, R.T., Houtgast, R.F. \& Cloetingh, S.A.P.L., 2005. Neotectonics of The Netherlands: a review. Quaternary Science Reviews 24: 439454.

Van der Weiden, M.J.J., 1983. Een hydrogeochemisch onderzoek in verband met de winning van aardwarmte uit het West-Nederland bekken, toegespitsts op het demonstratieproject Delfland. Rijksuniversiteit Utrecht (Utrecht), report.

Van Hulten, F.F.N., 2010. Geological factors effecting compartmentalization of Rotliegend gas fields in the Netherlands. In: Jolley, S.J., Fisher, Q.J., Ainsworth, R.B., Vrolijk, P.J. \& Delisle, S. (eds): Reservoir Compartmentalization. Geological Society Special Publication 347, the Geological Society (London): 301-315.

Verhoef, E., Neeft, E., Grupa, J. \& Poley, A., 2014. Outline of a disposal concept in clay. COVRA, report no. OPERA-PG-COV008.

Verweij, J.M., 1999. Application of fluid flow systems analysis to reconstruct the post-Carboniferous hydrogeohistory of the onshore and offshore Netherlands. Marine and Petroleum Geology 16: 561-579.

Verweij, J.M., 2003. Fluid flow systems analysis on geological timescales in onshore and offshore Netherlands. With special reference to the Broad Fourteens Basin. PhD Thesis. Vrije Universiteit (Amsterdam): $278 \mathrm{pp}$.

Verweij, J.M. \& Simmelink, H.J., 2002. Geodynamic and hydrodynamic evolution of the Broad Fourteens Basin (The Netherlands) in relation to its petroleum systems. Marine and Petroleum Geology 19: 339-359.

Verweij, H., Simmelink, E. \& Underschultz, J., 2011. Pressure and fluid flow systems in the Permian Rotliegend in the Netherlands onshore and offshore. SEPM special publication 98: 247-263.
Verweij, J.M., Simmelink, H.J., Underschultz, Witmans, N., 2012. Pressure and fluid dynamic characterisation of the Dutch subsurface. Netherlands Journal of Geosciences 91: 465-490.

Verweij, J.M., Simmelink, H.J., Van Balen, R.T. \& David, P., 2003. History of petroleum systems in the southern part of the Broad Fourteens Basin. Netherlands Journal of Geosciences 82: 71-90.

Vis, G.J., Verweij, J.M. \& Koenen, M., 2016. The Rupel Clay Member in the Netherlands: towards a better understanding of its depositional environment. Netherlands Journal of Geosciences, this issue.

Wong, T., Batjes, D.A.J. \& De Jager, J., 2007. Geology of the Netherlands. Royal Netherlands Academy of Arts and Science (Amsterdam): $354 \mathrm{pp}$.

Worden, R.H., Manning, D.A.C. \& Bottrell, S.H., 2006. Multiple generations of high salinity formation water in the Triassic Sherwood Sandstone: Wytch Farm oilfield, onshore UK. Applied Geochemistry 21: 455475.

Worum, G., Michon, L., Van Balen, R.T., Van Wees, J-D., Cloetingh, S. \& Pagnier, H., 2005. Pre-Neogene controls on present-day fault activity in the West Netherlands Basin and Roer Valley Rift System (southern Netherlands): role of variations in fault orientation in a uniform stress regime. Quaternary Science Reviews 24: 475-490.

Ziegler, K., 2006. Clay minerals of the Permian Rotliegend Group in the North Sea and adjacent areas. Clays and Clay Minerals 41: 355-393.

Zuurdeeg, B.W. \& Coenegracht, Y.M.A., 1986. Genesis of the mineral water of Nieuweschans. University of Utrecht, Department of Geochemistry, report.

Zuurdeeg, B.W., Coenegracht, Y.M.A., Mebius, J.E. \& Van der Weiden, M.J.J., 1984. Het mineraalwater van Winterswijk. Rijksuniversiteit Utrecht, afdeling Geochemie, report: 21 pp. 